Dr Ljiljana Kelemen Milojević

Milica Petrovićz, student master studija

Originalni naučni rad

UDK: 37.048 .2

Visoka škola strukovnih studija za vaspitače „Mihailo Palov”

Vršac

DOI: $10.5937 /$ IstrPed2102522K

\title{
MEĐUSOBNO POZDRAVLJANJE, OBRAĆANJE I OSLOVLJAVANJE VASPITAČA I DECE U PREDŠKOLSKIM USTANOVAMA
}

\begin{abstract}
Rezime: $U$ ovom radu donose se rezultati istraživanja o međusobnom pozdravljanju, obraćanju i oslovljavanju vaspitača i dece u predškolskim ustanovama iz perspektive vaspitača sa ciljem da se ispita trenutno stanje i otkrije da li postoji potreba za postavljanjem standardnih okvira kada je reč o prihvatljivim formama pozdravljanja, obraćanja i oslovljavanja među vaspitačima i decom u kontekstu predškolske ustanove. Shodno cilju, sačinjen je anketni upitnik koji je popunilo 152 vaspitača koji rade sa jaslenim i predškolskim vaspitnim grupama. Prikupljeni rezultati istraživanja prikazani su pomoću deskriptivne i analitičke metode i propraćeni kratkim diskusijama, s obzirom na problematiku pokrenutu određenim pitanjima. Rezultati istraživanja pokazuju da među ispitanicima postoji velika razlika u mišljenjima i stavovima o međusobnom pozdravljanju, obraćanju i oslovljavanju vaspitača i dece, te da je u narednom periodu neophodno razmatrati ovu temu u okviru predškolskih ustanova i doneti konkretnija pravila ponašanja u kojima će biti postavljeni standardni okviri o prihvatljivim formama pozdravljanja, obraćanja i oslovljavanja među vaspitačima i decom, a imajući u vidu uzrast dece i vaspitne grupe.
\end{abstract}

Ključne reči: obraćanje, oslovljavanje, pozdravljanje, pravilnici, predškolske ustanove.

\section{Uvodna razmatranja}

Pozdravljanje, obraćanje i oslovljavanje „čine složen sistem kulturnih, komunikacijskih lingvističkih i nelingvističkih pravila. Izbor i upotreba tih pravila uslovljeni su društvenokulturnim okvirom, situacionim kontekstom, intencijom sagovornika i određenim leksičkogramatičkim obeležjima konkretnog jezika" (Jocić, 2011: 297). Načini komunikacije i odnosi koji se uspostavljaju između vaspitača i deteta u predškolskoj ustanovi mogu da utiču na detetov celokupan razvoj. Kvalitet komunikacije i interakcije koji se uspostavlja između deteta i vaspitača, utiče, pre svega, na razvoj govora deteta, ali i na kvalitet rada i ostvarivanje vaspitne funkcije predškolske ustanove. Na svest vaspitača i dece o važnosti usmene reči izvesno je da utiču sve brži razvoj informacionih tehnologija, moć medija i sve kompleksniji zahtevi modernog društva i komunikacije u njemu. Takođe, širenje digitalnih tehnologija utiče na sve aspekte života - od socijalnih interakcija do načina na koji ljudi rade (up. Veljković Stanković i Đorđev, 2018).

\footnotetext{
1 ljiljakelemen@gmail.com

2 milicapetrovic210@gmail.com
} 
Usvajanje jezika i pravilan razvoj govora pružaju i književni tekstovi za decu. Književni tekst pruža detetu model upotrebe govora u različitim funkcijama i situacijama i pokazuje mu na koji način i u koju svrhu se može služiti govorom u svakodnevnom komuniciranju. Jedan od najznačajnijih srpskih pisaca za decu, Dušan Radović, kroz svoja mnogobrojna dela, uči nas, odrasle, kako se može komunicirati sa decom. U njegovoj poeziji nailazimo na forme dijaloga, pomoću kojih stvara iluziju da direktno oslovljava dete, što postiže upotrebom (v. Dotlić i Kamenov, 1996: 30; Kelemen Milojević, 2021: 99): 1) vokativa kojim direktno oslovljava dete (Poštovana deco!) i 2) imperativa (Zamislite, deco!). U stihovima ovoga pesnika ne nailazimo na oslovljavanje dece rečima kao što su drugari, klinci i sl.

Baveći se sistemima za oslovljavanje u različitim jezicima, američki psiholozi Rodžer Braun (Roger Brown) i Albert Gilman (Albert Gilman) objavili su rezultate svog istraživanja3, na osnovu kojih su pokušali da daju neku vrstu tipologije oslovljavanja u odnosu na dva osnovna semantička kriterijuma: solidarnost (solidarity) i autoritet ili moć (power). Solidarnost se odnosi na društvenu distancu sagovornika - neki ljudi se osećaju intimnijima, bližima, a ukoliko je distanca među njima veća, sagovornici će se međusobno oslovljavati tako da distanca među njima dođe do izražaja u govoru. Drugi kriterijum, tj. autoritet ili moć se objašnjava kroz odnose prema drugima u smislu socijalne hijerarhije ili nadređenog statusa jednih u odnosu na druge (up. Žiberg i Savić, 1982: 5).

U domaćoj naučnoj i stručnoj literaturi gotovo da nije opisano kako deca oslovljavaju odrasle na različitim uzrastima, niti kako to čine odrasli sa decom. Dosadašnja istraživanja o temi pozdravljanja, obraćanja i oslovljavanja u srpskom jeziku, u poslednje četiri i po decenije pokazuju da su prisutna dva toka u pristupu - jedan iz sociolingvistike, drugi iz psiholingvistike, a odnose se na različite uzrasne grupe: predškolske, osnovnoškolske, visokoškolske, kao i za odrasle osobe koje uče srpski kao strani, ili koji žive u dvojezičnoj vojvođanskoj sredini. „Empirijski podaci su uglavnom sakupljani pomoću upitnika ili ankete u sociolingvističkom pristupu, odnosno uglavnom na osnovu spontanih ostvarenih razgovora, primenom analize diskursa u psiholingvističkim istraživanjima. I jedna i druga istraživanja svode se na analizu jezičkih znakova za oslovljavanje i pozdravljanje" (Savić i Stanojević, 2012: 99).

O upotrebi zamenica ti/Vi u različitim situacijama pisale su Ivona Vasić (1979), Vesna Polovina (1983) i Bojana Milosavljević (2007), dok su o gramatičkim aspektima upotrebe ovih zamenica i nekih etiketa za oslovljavanje pisali Gordana Vuković (1980), Jovan Kašić (1987) i Milka Ivić (1989). Pozdravljanjem i oslovljavanjem na mađarskom jeziku u Vojvodini bavi se Edita Andrić (2012). Andrić u svom radu navodi najosnovnije oblike pozdravljanja u mađarskom jeziku, kao i neke specifičnosti u načinu oslovljavanja sagovornika prema polu, starosnoj dobi, bračnom stanju, rodbinskim odnosima, društvenim i situacionim ulogama, oslovljavanju u medijima i privatnom životu i upotrebi ličnih zamenica sa ciljem oslovljavanja. Katalin Ozer (2011) i Julijana Jovičić (2012) istraživale su i pisale o oslovljavanju u nemačkom i srpskom jeziku u Vojvodini i Nemačkoj (uporedna analiza). O obraćanju i pozdravljanju u romskom jeziku, u studentskoj populaciji na teritoriji Vojvodine, pisale su Marija Aleksandrović, Svenka Savić i Danijela Stanojević (2012: 10-32) i, pritom, u svom pilot istraživanju, došle su do zaključka da studentkinje i studenti dosledno koriste u međusobnom obraćanju formu Ti, a u pozdravljanju najčešće koriste izraz ćao, dok se u javnoj sferi uglavnom pozdravljaju sa lačho dive - dobar dan, a ostalima se obraćaju zamenicom Vi. Autorke ističu i da je uočen sve veći uticaj stranih izraza prilikom pozdravljanja u romskoj zajednici među mladima - iz italijanskog (Ciao) i

3 Više videti u: Brown, \& Gilman, 1972: 252-282. 
engleskog (Hello), kao i iz srpskog jezika (zdravo), a pod uticajem elektronskih medija. O oslovljavanju i pozdravljanju kod Bunjevaca pisale su Mirjana Savanov i Nevenka Bašić Palković (2012), upoređujući način na koji se danas oslovljava i pozdravlja sa onim kako se to nekada činilo. Među mlađom generacijom se, kako autorke navode, može čuti Ej, ćao, kako si, žurim, vidimo se na fejsu!, umesto nekadašnjeg pozdrava Hvaljen Isus i Marija! ili Ljubim ruke, nane! O pozdravljanju, oslovljavanju i obraćanju vojvođanskih Hrvata pisala je Mila MarkovŠpanović (2012), dok su Laura Spariosu i Ivana Janjić (2012) dale kratak prikaz formula za oslovljavanje, pozdravljanje i obraćanje u savremenom rumunskom jeziku, posvećujući posebnu pažnju socijalnom aspektu pozdravljanja i njegovim komunikacijskim, faktičkim i konativnim funkcijama, te su analizirale i primere iz svakodnevnog govora i jezika medija na rumunskom jeziku u Vojvodini. Natalija Šarko-Golubović (2012) je predstavila okvirni sistem govorne komunikacije ukrajinske nacije, njegovu opštu stranu i regionalnu specifičnost na prostorima Vojvodine u konstantnom dodiru sa jezicima i kulturama različitih nacionalnih zajednica, u formalnim, neformalnim i neutralnim situacijama, te je zaključila da postoji tendencija smanjivanja formalnosti u komunikaciji (up. Stanojević, 2012: 7-9).

Nešto konkretnije, i za našu temu značajne rezultate istraživanja o međusobnom oslovljavanju odraslih i dece predškolskog uzrasta na našem govornom području daju Vera Vasić (1979; 1983), Mirjana Jocić (1981) i Ivona Žilberg u koautorstvu sa Svenkom Savić (1982). Vera Vasić (Vasić, 1979: 175) ističe da na oslovljavanje utiče starosno doba odraslih članova porodice, zatim onih osoba koje imaju česte kontakte sa decom, a najvažniji je stav odraslih članova porodice prema modelu oslovljavanja koje razvija dete. Takođe, ova autorka zaključuje da deca na ranom uzrastu upotrebljavaju lično ime i termine za označavanje rodbinskih odnosa, a ređe nadimak (npr. tetka Dana, teta Mira, uja Pera), kao i da u govoru deteta predškolskog uzrasta već postoji više različitih načina oslovljavanja odrasle osobe (kada potpuno izostaje oslovljavanje odraslih osoba etiketama gospodin, gospođa, gospođica, drug). U svom drugom radu Vasić (1983) daje inventar verbalnih znakova za oslovljavanje, kao što su lično ime ili samo glagolska forma (Daj mi). Mirjana Jocić (1981) smatra da je predškolska ustanova, kao jedan od bitnih faktora razvoja i socijalizacije deteta, veoma podsticajna za razvoj verbalne komunikacije kod dece, a u okviru toga i inventara reči i izraza za oslovljavanje i pozdravljanje. Istraživanje, koje je sprovela sa Verom Vasić u novosadskoj predškolskoj ustanovi jednom mesečno tokom jedne školske godine usmereno je na komunikaciju vaspitačice sa decom, pri čemu je zabeleženo da je komunikaciju obično započinjala vaspitačica, da se ona najčešće obraćala čitavoj grupi dece koristeći se etiketama i izrazima: Deco! Dečice! Mili moji...; Mali moji...; 'Ajde da// Hajde da...; Idemo... itd. Kada se obraćala deci pojedinačno, koristila je najčešće ime deteta, kao i hipokoristične etikete: dušo, srce, sine, maco... Svakom detetu se obraćala zamenicom ti i glagolskim oblikom u jednini. Deca su vaspitačicu oslovljavala isključivo formom Ti i njenim ličnim imenom. Žilberg i Savić (1982) u svom istraživanju dolaze do zaključka da deca, usvajajući sistem za oslovljavanje u maternjem (srpskohrvatskom) jeziku na ranom uzrastu, najpre poseduju svoj proto-sistem različit od onog kakav upotrebljavaju odrasli. Takav prvobitni sistem sadrži, pored reči za oslovljavanje (lično ime, nadimak, termini za označavanje rodbinskih odnosa, zamenički oblici ti, ređe $V i)$, i kontaktne forme, tj, reči za skretanje pažnje u našem jeziku koje se upotrebljavaju u kolokvijalnom razgovoru, kao što su: evo, eto, eno, ej, vidi, pogledaj, halo itd. Takođe, ove autorke smatraju da proto-sistem za oslovljavanje održava bliske odnose među sagovornicima, najčešće roditeljima i deci poznatim odraslim osobama u govornoj okolini. Autorke procenjuju da se prelazak od forme Ti na formu Vi kod dece predškolskog uzrasta, kao znak veće društvene senzibilnosti, događa tek u godini pre polazak u školu ili ulaskom u školsku sredinu. 


\section{Pozdravljanje, obraćanje i oslovljavanje kao forme komunikativnih diskursa}

U srpskom jeziku javlja se mnogo različitih vidova usmenog izražavanja u neposrednoj usmenoj komunikaciji. Po karakteru i funkciji dele se u dve vrste diskursa: komunikativne i ekspresivne (interpretativne i kreativne). $U$ komunikativne diskurse ubrajaju se govorni događaji koji imaju ustaljenu formu u svakodnevnoj komunikaciji kao što su: pozdravljanje, obraćanje i oslovljavanje, čestitanje, diskusija na sastancima i konferencijama, rasprava na radiju i televiziji i drugi. Svaki diskurs „,karakterišu posebna pravila ponašanja i poseban izbor jezičkih sredstava kojim se ostvaruju" (Šipka, 2008: 212-213). U ovom radu je akcenat stavljen na prve tri pomenute forme komunikativnih diskursa.

Pozdravljanje i oslovljavanje se sagledavaju kao govorni činovi, koji kao društveno konvencionalni obrasci ponašanja, mogu biti preduslov uspešne komunikacije, ali i izvor namernih ili iz neznanja započetih nesporazuma. Kao prvi korak verbalne ili neverbalne, javne ili privatne, pismene ili usmene komunikacije, ovi govorni činovi su uslovljeni mnogobrojnim kulturnim, lingvističkim i nelingvističkim pravilima i faktorima kao što su stepen poznatosti, kontekst (mesto, vreme, pol, životna dob), socijalni status, bliskost, kulturno ili jezičko nasleđe itd. Od ovih faktora zavisi izbor iz obilja načina kako ćemo osloviti ili pozdraviti učesnika/e u komunikaciji: zvanično, učtivo, distancirano, solidarno ili familijarno (Stanojević, 2012: 7).

Društveno prihvatljive obrasce ponašanja treba sagledati u kontekstu samopoštovanja, koncepta kojim su intenzivno počeli da se bave američki istraživači sedamdesetih godina prošloga veka i koji je, od tada, često kritikovan zbog nedostatka empiriske podrške u svim aspektima ljudskog ponašanja. Samopoštovanje se sastoji od toga kako osoba razmišlja o sebi i na koji način sebe procenjuje, te je zato ocenjena kao procenjivačka komponenta samospoznaje. Visoko samopoštovanje odnosi se na izuzetno povoljnu globalnu procenu sebe, dok se nisko samopoštovanje, po definiciji, odnosi na nepovoljnu definiciju sebe. Stoga je samopoštovanje percepcija, a ne stvarnost. Ljudi sa visokim samopoštovanjem su spremniji od drugih da izaberu sopstvenu strategiju i više reaguju na situacije koje ukazuju na to kada treba ustrajati, a kada preći na alternativu koja više obećava (Baumeister et al., 2003). Mnogi ljudi, kao bića koja su svesna sebe i razmišljaju o sebi, intuitivno prepoznaju važnost samopoštovanja (Baumeister, Dale, \& Sommer, 1998). Rečju, uverenja ljudi oblikuju lične postupke na mnogo načina, a ti postupci ujedno oblikuju njihovu društvenu stvarnost $i$ društvenu stvarnost ljudi u njihovom okruženju. S jedne strane, poznavanje sebe moglo bi pomoći ljudima da pravilno odaberu svoje zanimanje, svoju profesiju i smer u kome bi trebalo da se usavršavaju. S druge strane, samopoštovanje jeste preduslov za poštovanje prema drugima.

Tražeći specifične odnose između samopoštovanja i promenljivih interesa, poput zdravlja, inteligencije, učinka i zadovoljstva poslom i međuljudskim odnosima, kao i odgovor na pitanje da li samopoštovanje uzrokuje bolje performanse, međuljudski uspeh, sreću ili zdravije stilove života, američki istraživači Baumajster (Roy F. Baumeister), Kembel (Jennifer D. Campbell), Kruger (Joachim I. Krueger) i Vos (Kathleen D. Vohs) došli su do zaključka da se samopoštovanje podstiče samopoboljšanjem, te da povoljan pogled na sebe treba promovisati na osnovu dobrog rada i moralnog ponašanja. Između ostalog, pomenuti istraživači preporučuju upotrebu pohvala za povećanje samopoštovanja kao nagrade za društveno poželjno ponašanje i samopoboljšanje i smatraju da samopoštovanje treba koristiti na ograničen način kao jedan od mnogobrojnih faktora za promociju pozitivnih ishoda ( $v$. Baumeister et al., 2003). 
Pozdravljanje. Pre ostvarivanja bilo kakvog vida komunikacije, ljudi se međusobno susreću i tom prilikom upućuju jedni drugima različite pozdrave, koristeći se neverbalnim ili verbalnim sredstvima ili istovremeno koristeći oba. Verbalnim sredstvima, tj. Posebnim rečima i izrazima koje ljudi upućuju jedni drugima u znak pozdrava pri susretima ujedno se iskazuju i različite želje: za dobro zdravlje, mir, sreću, dug život, izražava se poštovanje ili pokornost. Verbalni pozdravi imaju pozitivno značenje u svim jezicima na svetu. „Pozdravi spadaju u jezičku etikeciju, ali njihov jezički inventar, izbor i pravila upotrebe, uglavnom nisu zvanično propisani. Obično su to stereotipni izrazi rezervisani za određene situacije i iskazivanje određenih intencija govornika prema sagovorniku kojem su upućeni...” (Jocić, 2011: 331).

Prilikom međusobnih susreta ili rastanaka, pripadnici različitih konfesija upotrebljavaju „građanske” pozdrave, kao što su: Zdravo!, Dobro jutro!, Dobar dan!, Dobro veče!, Do viđenja!, Laku noć! I sl., što je uobičajeno i za urbane sredine, ali i u službenoj komunikaciji. Pojedine društvene grupe imaju svoje karakteristične pozdrave. Među mladima na našim prostorima je zastupljen pozdrav Ćao!, koji nam je preko Dalmacije došao iz venecijanskog italijanskoga govora (v. Šipka, 2008: 216), kao i strani izrazi Hello! Ili Hi. Pozdrav sa Ljubim ruke ili Moj naklon davno su izašli iz upotrebe (v. Elektronski izvor: Bonton - pravila lepog ponašanja).

Osim verbalnih, treba pomenuti i neizostavna neverbalna sredstva pozdravljanja, kao što su: rukovanje, zagrljaj, klimanje glavom, naklon, podizanje ruke ili mahanje, skidanje šešira, a u nekim zajednicama trljanje noseva (kod Eskima i Polinežana). Svi ovi neverbalni znakovi imaju svoju simboliku - prijateljstvo, poštovanje, odanost, simpatija, bliskost itd. Upotreba ovih znakova određena je tradicijom i običajima određene zajednice, a uz to ukazuje i na emocionalne i socijalne odnose pa je time i društveno uslovljen čin.

Kultura verbalne i neverbalne komunikacije podrazumeva poznavanje svih pozdrava i njihov odgovarajući izbor u različitim okolnostima, unutar svoje profesije, između urbane i ruralne sredine, između mlađih i starijih i slično. Ne bi bilo primereno kada bi se neki učenik obratio svom profesoru sa Ćao! U takvim situacijama upotrebljava se isključivo formalno pozdravljanje: Dobar dan! Dobro veče! Itd. Dakle, pozdravljanjem se pokazuje ne samo nivo kulture govora, nego i kultura međusobnih odnosa članova jedne zajednice (Šipka, 2008: 213217).

Obraćanje i oslovljavanje. Prilikom (sa)obraćanja i oslovljavanja u jednoj govornoj zajednici, izbor jezičkih sredstava društveno je i kulturološki uslovljen, kao i u slučaju pozdravljanja. U jezička sredstva za oslovljavanje i obraćanje spadaju: 1) leksičke jedinice ili etikete (reči i izrazi) - imena, prezimena, nadimci, nazivi za označavanje srodstva, zanimanja ili profesije, titule, društvene funkcije, semantički nespecifično obeležena ili „,manje obeležena jezička sredstva kao što su npr. Drug, drugarica, gospodin, gospođa, kolega, koleginica, komšija, komšinica, dečko, devojčica, momak, devojka, mali, mala, tetka, čika itd." (Radovanović, 1986: 140), ustaljeni pozdravi, stereotipne učtive (Izvinite, Oprostite, molim Vas, Pardon...) i neučtive konstrukcije (Hej, ti!, Ej, bre!); 2) gramatička sredstva - lična zamenica ti drugog lica jednine i lična zamenica vi drugog lica množine upotrebljena umesto zamenice ti u značenju drugog lica singulara; vokativ, a ponekad nominativ (Momak, pomeri se!) u vokativnoj funkciji imenica, kao i lični nastavci za drugo lice jednine (Glasaj za prave vrednosti!) i drugo lice množine (Oslobodite prolaz, molim vas!) imperativa kod glagola (Jocić, 2011: 300). „Važna univerzalna, za sve jezike važeća činjenica, o isprepletenosti jezika sa drugim društvenim fenomenima koji utiču na jezičku upotrebu I modifikuju je, rezultirala je stavom da raznolikost jezičkih upotreba zavisi od raznolikosti vanjezičke situacije" (Isto: 299). Univerzalna sposobnost prilagođavanja jezika vanjezičkoj situaciji se u literaturi naziva komunikativnom kompetencijom, koja podrazumeva sistem društvenih vrednosti i pravila, bonton određene 
društvene zajednice, odnosno društvene grupe (ko se prvi javlja, ko prvi pruža ruku, kako se ponaša u privatnoj, a kako u javnoj sferi, kako u formalnoj, a kako u neformalnoj situaciji i sl.) (Hajmz, 1980).

Prvo što zapažamo u vezi sa verbalnom komunikacijom ljudi na našem govornom području jeste upotreba ličnih zamenica za drugo lice jednine (ti) i drugo lice množine (vi), u oba slučaja u obraćanju jednoj osobi. Ljudi se nisu oduvek obraćali nekim osobama sa Vi, što potvrđuju i srpske narodne pesme i priče (Šipka, 2008: 218). Obraćanje sa Vi nastalo je u IV veku nove ere u Rimskom carstvu, i to samo carevima. Taj običaj se proširio i ustalio u Zapadnoj Evropi tek u srednjem veku. Upotreba ličnih zamenica ti ili Vi u obraćanju pojedinim osobama nije gramatičko, tj. Čisto lingvističko pitanje, već se radi o „funkciji isticanja prirode odnosa među govornim predstavnicima datog jezika odnosno kolektiva koji je u pitanju, kao i o ulozi upućivanja na relativni društveni status komunikatora u ostvarenom govornom događaju (naravno, i u okviru ostvarene interakcijske situacije u datoj govornoj zajednici) - tj. Na status jednog učesnika u njemu u poređenju sa statusom drugog” (Radovanović, 1986: 135).

Međusobni odnos dvaju komunikatora, označen ličnim zamenicama ti ili Vi, izražava se sledećim relacijama: 1) $t i-t i, 2) V i-V i$, 3) ti - Vi i 4) Vi - ti. Međusobno obraćanje komunikatora sa ti sugeriše njihovu bliskost i ravnopravnost, odnosno solidarnost. Obraćanje sa ti iskazuje bliskost i u odnosu dece i roditelja, kao i bližih rođaka, ali sve to zavisi od kulture i različitih tradicija. Obraćanje sa Vi ukazuje na društvenu i emocionalnu distancu komunikatora, na službeni odnos, bez bliskosti, čak i određenu rezervisanost jednih prema drugima, zbog nedovoljnog poznavanja ili nekog drugog razloga. Različito obraćanje komunikatora ( $\mathrm{ti}$ - Vi ili obrnuto) pokazuje neravnopravnost i statusnu nejednakost komunikatora - generacijsku (odnos stariji - mlađi) ili društvenu (odnos nadređeni podređeni) i slično. Tako se stariji obraćaju deci i (mnogo) mlađima od sebe sa ti, a deca i mlađi starijima sa Vi. Svako remećenje ovih pravila, prelazak sa Vi na ti, ili obrnuto, ukazuje na promenu odnosa govornih lica u komunikaciji, a obraćanje sa ti umesto na Vi nepoznatim osobama, pogotovo u službenim odnosima pokazuje nepoštovanje i potcenjivanje onoga sa kojim se komunicira i uspostavljanje odnosa nadređenosti i podređenosti, ukazujući na neuljudnost i odsustvo kulture komunikacije uopšte. Jedan od uzroka ove pojave jeste ruralizacija gradova na našem podneblju (Šipka, 2008: 217-220).

Odnosi koji se izražavaju različitom upotrebom ličnih zamenica ti i Vi u međusobnom (sa)obraćanju prati i odgovarajući izbor drugih jezičkih sredstava i taj izbor je društveno uslovljen. Jedan od tih jezičkih sredstava jeste i oslovljavanje drugih osoba sa kojima komuniciramo. „Oslovljavanje je jedan od verbalnih načina započinjanja razgovora sa sagovornikom i osnovna mu je funkcija uspostavljanje kontakta (skretanje pažnje, zadržavanje sagovornika u razgovoru, itd.)" (Žiberg i Savić, 1982: 5). Na osnovu kriterijuma pripadnosti jezičkih sredstava u funkciji oslovljavanja određenoj vrsti reči, pre svega, razlikujemo zameničke (pronominalne: Ti/Vi) i imeničke (nominalne: lično ime, nadimak, etikete za oslovljavanje) oblike ili forme oslovljavanja (Braun, 1988: 7). O oslovljavanju kao obliku socijalnog govornog ponašanja pisano je kao o pojavi koja zavisi od statusa, uzrasta, zanimanja ili bliskosti sagovornika (Žiberg i Savić, 1982: 7). Ljude sa kojima smo bliski treba da oslovljavamo samo ličnim imenom, hipokoristikom (imenom odmila) ili nadimkom. Nepoznate odrasle osobe oslovljavamo samo sa gospodine ili gospođo, a decu sa seko, bato, dečko i sl. U službenoj komunikaciji pretpostavljene oslovljavamo sa: gospodine direktore, gospodine profesore (Šipka, 2008: 220).

S obzirom na to da izbor jezičkih sredstava ne zavisi od jezičkih, već od vanjezičkih (društvenih) faktora, pravila komunikacije u srpskome jeziku nisu regulisana 
standardnojezičkim priručnicima (gramatike, pravopisi, rečnici) i pravilnicima. Nedostatak jezičkih priručnika i društveno dogovorenih pravila komunikativnog ponašanja najviše pogađa javnu sferu, pre svega masovne medije, zatim statusno označene okvire: predškolske ustanove, školu, vlast, sudnicu, vojsku, crkvu itd. (Jocić, 2011: 299). Deo tih pravila daje se u vidu saveta i preporuka u knjigama o lepom ponašanju, kao što su: Bonton autorke Jasminke Petrović ( $\left.{ }^{8} 2019\right)$, namenjen predškolskom i mlađem školskom uzrastu i Pravopis srpskoga jezika (2010) Matice srpske, u kome su date odredbe o velikom početnom slovu u pisanju reči iz poštovanja, odnosno u pisanju zamenica Vi, Vaš, Vas.

U svakoj društvenoj i jezičkoj zajednici postoje standardi - sistem pravila obaveznih za sve one koje tim jezikom govore i pišu (up. pravopisna, gramatička pravilnost). Gramatički i pravopisni standardi smatraju se i naučnom i društvenom brigom o jeziku kako bi se obezbedila uspešna i kvalitetna komunikacija (Đorđev, Kelemen Milojević i Đorđević, 2017: 9). Odlučujuću ulogu u negovanju normi treba da ima vaspitno-obrazovni sistem. Nažalost, iako se na svesnom nivou zna važnost poštovanja pravila, neretko se dogodi da se ona površno poštuju i parcijalno primenjuju (up. poštovanje pravopisnih pravila i sl., Đorđev 2016: 41-53). Međutim, šta bi bilo kada ne bi postojala sva ta pravila koje nije lako u celosti poznavati i pridražavati ih se? Ovo pitanje nas podstiče na odgovor koji otkriva svest o nužnosti postojanja i poštovanja norme - „da pravila nema, morali bismo ih stvoriti” (Veljković Stanković i Đorđev, 2018: 17).

Imajući sve ovo u vidu, sproveli smo istraživanje mišljenja i stavova vaspitača o međusobnom pozdravljanju, obraćanju i oslovljavanju vaspitača i dece u predškolskim ustanovama, kao i o potrebi za postavljanjem standardnih okvira o prihvatljivim formama u okviru komunikativnih diskursa. Metodološki okvir istraživanja, kao i rezultate donosimo u nastavku.

\section{Metodološki okvir istraživanja}

Predmet našeg istraživanja jesu mišljenja i stavovi vaspitača o pozdravljanju, obraćanju i oslovljavanju između njih i dece u predškolskim ustanovama. Osnovni problem istraživanja može se formulisati u vidu sledećeg pitanja: Postoji li potreba za postavljanjem standardnih okvira kada je reč o prihvatljivim formama pozdravljanja, obraćanja i oslovljavanja među vaspitačima i decom u kontekstu predškolske ustanove?

Osnovni cilj istraživanja jeste otkrivanje forme pozdravljanja, obraćanja i oslovljavanja među decom i vaspitačima u predškolskim ustanovama, kao i mišljenja i stavova vaspitača o ovim formama komunikativnih diskursa s obzirom na vaspitne grupe sa kojima rade. Na osnovu postavljenog cilja istraživanja, proistekli su sledeći istraživački zadaci: 1) ispitati da li predškolske ustanove, u kojima rade ispitanici, imaju pravilnik u kome su određena pravila o komunikativnim diskursima - međusobnom pozdravljanju, oslovljavanju i obraćanju; 2) ispitati na koji način deca predškolskog uzrasta pozdravljaju i oslovljavaju svoje vaspitače i na koji način im se obraćaju; 3) ispitati na koji način vaspitači pozdravljaju i oslovljavaju decu predškolskog uzrasta; 4) utvrditi postoji li razlika u mišljenjima i stavovima vaspitača s obzirom na: mesto u kome rade, na pol i s obzirom na dosadašnje radno iskustvo i 5) ispitati na koji način su se vaspitači upoznali sa temom pozdravljanja, obraćanja i oslovljavanja u predškolskim ustanovama.

U skladu sa problemom, ciljem i zadacima istraživanja, osnovna hipoteza od koje smo u analizi pošli jeste: Postoji izražena potreba za postavljanjem standardnih okvira kada je reč o prihvatljivim formama pozdravljanja, obraćanja i oslovljavanja među vaspitačima i decom u kontekstu predškolske ustanove. 
Pomoćne hipoteze su brojne:

- H1: Predškolske ustanove nemaju pravilnik u kojem su određena pravila o komunikativnim diskursima - međusobnom pozdravljanju, oslovljavanju i obraćanju dece i vaspitača.

- H2: Deca predškolskog uzrasta u pozdravljaju i oslovljavaju svojih vaspitača, kao i u obraćanju više koriste neformalne jezičke izraze i/ili etikete.

- H3: Vaspitači više koriste neformalne jezičke izraze i etikete kada oslovljavaju decu, dok za pozdravljanje koriste formalne jezičke izraze.

- H4: Postoji razlika u mišljenjima i stavovima ispitanika o međusobnom pozdravljanju, obraćanju i oslovljavanju vaspitača i dece u predškolskim ustanovama s obzirom na mesto u kome rade, na pol i s obzirom na dosadašnje radno iskustvo.

- H5: Vaspitači su se upoznali sa temom pozdravljanja, obraćanja i oslovljavanja u predškolskim ustanovama u toku svog formalnog obrazovanja.

Za potrebe istraživanja izdvojili smo nezavisne varijable: 1) pol ispitanika; 2) mesto u kome vaspitač radi; 3) godine radnog staža i 4) vaspitne grupe sa kojom vaspitač radi. Zavisne varijable istraživanja jesu: 1) mišljenje i stavovi vaspitača o međusobnom pozdravljanju u PU4; 2) mišljenje i stavovi vaspitača o međusobnom obraćanju u PU; 3) mišljenje i stavovi vaspitača o međusobnom oslovljavanju u PU.

Priroda i svrha istraživanja uslovile su opredeljenje za namerni uzorak - istraživanjem je obuhvaćeno ukupno 152 vaspitača (v. Tabelu 1) iz: PU „Čarolija”, Vršac (83 vaspitača), PU „Majski cvet”, Veliko Gradište (32 vaspitača), PU „Vračar”, „Rakovica”, „Čukarica”, „Dečji dani”, „Dr Sima Milošević”, „Pametnica-Diplomat”, „,Dediks Kids”, „Kung Fu Panda”, „,Step by step” itd., Beograd (19 vaspitača), PU „Kolibri”, Kovačica (4 vaspitača), PU „Srećno detinjstvo", Plandište (3 vaspitača) i ostalih PU iz Pančeva, Smedereva, Aranđelovca, Sopota, Bele Crkve i Banatskog Karlovca (11 vaspitača).

Tabela 1. Uzorak istraživanja

\begin{tabular}{lll}
\hline Nezavisne varijable & $\mathrm{f}$ & $\%$ \\
\hline Pol & Ženski -149 & 98 \\
Mesto & Muški -3 & 2 \\
& Vršac -83 & 54.6 \\
& Veliko Gradište -32 & 21.1 \\
& Beograd - 19 & 12.5 \\
Godine radnog staža & Ostala mesta - 18 & 11.8 \\
& Manje od godinu dana (10) & 6.6 \\
& $1-5(29)$ & 19.1 \\
& $5-10(27)$ & 17.8 \\
& $10-20(57)$ & 37.5 \\
Vaspitna grupa u kojoj & $20-30(22)$ & 14.5 \\
vaspitač radi & Preko 30 godina (7) & 4.6 \\
& Jaslena grupa - 35 & 23 \\
& Mlađa obdanišna grupa -22 & 14.5 \\
& Srednja obdanišna grupa - 27 & 17.8 \\
& Starija obdanišna grupa - 17 & 11.2 \\
\hline Ukupno & Mešovita obdanišna grupa - 17 & 11.2 \\
\hline
\end{tabular}

${ }^{4}$ Ova skraćenica (PU - predškolska ustanova) će se u daljem tekstu upotrebiti sa ciljem ekonomičnosti i preglednosti pri pisanju teksta.

${ }_{5}^{5}$ Danas se u praksi sve više koristi izraz: grupa u godini pred polazak u školu. 
Uzorak je obuhvatio vaspitače koji rade sa predškolskim grupama svih uzrasta: jaslenom, mlađom, srednjom, starijom, mešovitom i pripremnom predškolskom grupom (grupom u godini pred polazak u školu). Među ispitanicima ima i studenata koji pohađaju studije drugog nivoa (master strukovne studije) Visoke škole strukovnih studija za vaspitače „Mihailo Palov”, Vršac. Takođe, ima i diplomiranih studenata ove visokoškolske ustanove. Od ukupnog broja ispitanika, samo $2 \%$ je muškog pola (3 vaspitača), a $98 \%$ je ženskog pola (149 vaspitačica). Više od polovine ispitanika je iz Vršca (54,6\%). Najviše ispitanika (više od trećine ispitanika: $37,5 \%$ ) radi u prosveti između deset i dvadeset godina, dok četvrtina ispitanika radi između pet i deset godina $\mathrm{i}$ isto toliko radi između dvadeset $\mathrm{i}$ trideset godina. Kada je reč o vaspitnim grupama, najviše ispitanika radi sa jaslenim i pripremnim predškolskim grupama, dok ostali rade u obdanišnim grupama, što smatramo relevantnim uzorkom za potrebe našeg istraživanja.

Prikupljeni rezultati istraživanja obrađeni su u programu SPSS Statistics 17.0., te prikazani pomoću deskriptivne i analitičke metode i propraćeni kratkim diskusijama, s obzirom na problematiku pokrenutu određenim pitanjima. Kada je reč o prirodi istraživačkog problema, za ovu priliku sačinjen je anonimni anketni upitnik za vaspitače koji sadrži 14 pitanja mešovitog (otvorenog i zatvorenog) tipa (v. Prilog). Istraživanje je realizovano u periodu od 21. januara do 21. februara 2020. godine (Međunarodnog dana maternjeg jezika).

\section{Rezultati istraživanja i diskusija}

Na osnovu člana 109. stav 3. a u vezi sa članom 119. stav 1. tačka 1) Zakona o osnovama sistema obrazovanja i vaspitanja ${ }^{6}$, svaka „ustanova je dužna da aktom uredi pravila ponašanja i međusobne odnose dece, učenika, roditelja, odnosno drugih zakonskih zastupnika i zaposlenih u [predškolskoj] ustanovi" (Član 109. stav 3. Pravila ponašanja u ustanovi). U skladu sa tim, ispitanici su se najpre u anketnom upitniku izjasnili da li u predškolskim ustanovama, u kojima su zaposleni, postoji pravilnik sa određenim pravilima o komunikativnim diskursima - o međusobnom pozdravljanju, oslovljavanju i obraćanju zaposlenih i dece. Nešto manje od dve trećine ispitanika, tačnije $65,1 \%$ izjasnilo se da njihova predškolska ustanova ima pravilnik o ponašanju, ali u njemu nisu regulisani načini, forme, niti pravila komunikacije između vaspitača i dece. Samo $15,8 \%$ ispitanika je istaklo da njihova predškolska ustanova nema pravilnik, dok petina ispitanika (19,1\%) nije sigurna (v. Tabela 2$)$.

Tabela 2. Da li u Vašoj predškolskoj ustanovi postoji pravilnik u kome su određena pravila o komunikativnim diskursima?

\begin{tabular}{lcc}
\hline Odgovori vaspitača: & $\mathrm{f}$ & $\%$ \\
\hline Nema pravilnik & 24 & 15.8 \\
Ima pravilnik & 99 & 65.1 \\
Ne znam/nisam siguran/na & 29 & 19.1 \\
\hline Ukupno & 152 & 100.0 \\
\hline
\end{tabular}

Podrobnom analizom nekoliko Pravilnika o ponašanju pojedinih predškolskih ustanova, došli smo do zaključka da se pravila o ponašanju, u najboljem slučaju, odnose na oslovljavanje korisnika usluga (roditelja i ostalih zakonskih staratelja dece) od strane vaspitača i ostalih zaposlenih u PU:

\footnotetext{
${ }^{6}$ V. Elektronski izvor: Zakon o osnovama sistema obrazovanja i vaspitanja (,Sl. glasnik RS”, br. 88/2017, 27/2018 - dr. zakon, 10/2019, 27/2018 - dr. zakon i 6/2020), 40 str.
} 
Član 8. Ponašanje zaposlenih u ustanovi. U svom radu zaposleni treba da sa decom, roditeljima, ostalim zaposlenima i drugim licima uspostave odnose zasnovane na uvažavanju, razumevanju i poštovanju, toleranciji i izbegavanju sukoba. Svađe, vređanja, ignorisanje i otvorena netrpeljivost među zaposlenima nisu dozvoljene.

Član 9. Ponašanje zaposlenih u ustanovi. Zaposleni su dužni da se u kontaktu sa korisnicima usluga ponašaju profesionalno uz distancu i poštovanje. Obraćaju se sa „Vi”, „Gospodine”, „Gospođo”, nikako „Majko”, „Tata” i sl. A deci se obraćaju i koriste izraze „molim”, „,hvala”, „izvoli”, „izvini” u svakodnevnim situacijama. Zaposleni prvi pozdravlja i otpozdravlja korisnike i druga lica, uz prijatan izgled lica bez intimiziranja prilikom pozdravljanja, kao i pozdravljanja gestovima, dizanjem ruku i sl. (Pravila ponašanja u predškolskoj ustanovi „Čukarica”, 2015: 3).

Član 48. Pravila komunikacije zaposlenih. Kontakt sa roditeljima i strankama treba da budu u skladu sa pravilima poslovnog komuniciranja: Zaposleni prvi pozdravlja stranku uz prijatan izraz lica i osmeh. Stranka sve vreme treba da bude u polju pažnje zaposlenog i vizuelnom kontaktu. Intimniji način pozdravljanja se ne preporučuje. Roditeljima i strankama se isključivo obraća sa „Vi” (Pravila ponašanja u predškolskoj ustanovi „Čarolija” Vršac dece, zaposlenih i roditelja, 2015: 13).

Član 5. stav 1. tačka 2) Obaveze i dužnosti zaposlenih. Vaspitni kadar je nosilac vaspitno-obrazovnog rada u Ustanovi. Svojim zalaganjem, radom i stručnošću, vaspitači, medicinske sestre i svi zaposleni su dužni svojim ponašanjem u odnosu prema deci, roditeljima i drugim zaposlenim, budu uzor deci... (Pravila ponašanja dece, zaposlenih i roditelja u predškolskoj ustanovi „Majski cvet” u Velikom Gradištu, 2018: 1-2).

Forme komunikacije $u$ analiziranim pravilnicima svode se na interna pravila koja postoje $u$ svakoj predškolskoj ustanovi i deo su kulture življenja, čime je potvrđena naša prva pomoćna hipoteza da predškolske ustanove nemaju pravilnik u kome su određena pravila o komunikativnim diskursima - međusobnom pozdravljanju, oslovljavanju i obraćanju vaspitača i dece.

Pozdravljaje, oslovljavaje i obraćanje vaspitača u predškolskim ustanovama. Da bismo došli do saznanja na koji način deca pozdravljaju svoje vaspitače, ispitanicima je postavljeno pitanje: Na koji način deca Vas pozdravljaju? Više od polovine vaspitača $(59,9 \%)$ odgovorilo je da ih deca pozdravljaju ponekad rečju ,zdravo”, a ponekad sa „dobro jutro / dobar dan” / „do viđenja”, dok ih najređe (3,3\%) pozdravljaju samo rečju „zdravo”. Ovakvi rezultati istraživanja su i očekivani, ako se pozovemo na okvirne standarde socijalnog razvoja dece mlađeg uzrasta (v. Standardi za razvoj i učenje dece ranih uzrasta u Srbiji, 2012), prema kojima deca pozdravljaju odrasle koristeći i formalne i neformalne jezičke izraze. Potpuniju sliku o načinu pozdravljanja vaspitača od strane dece dobili smo kada smo uporedili način pozdravljanja sa vaspitnim grupama u kojima trenutno rade. Rezultati su predstavljeni u tabeli 3. 
Tabela 3. Načini pozdravljanja vaspitača u predškolskim ustanovama u zavisnosti od vaspitne grupe

\begin{tabular}{|c|c|c|c|c|c|c|}
\hline & & & Na koji način deca & Vas pozdravljaju? & & \\
\hline & & $\begin{array}{c}\text { Rečju } \\
\text { „zdravo” }\end{array}$ & $\begin{array}{c}\text { Pozdravljaju me } \\
\text { sa } \\
\text { „dobro jutro / } \\
\text { dobar dan” / „,do } \\
\text { viđenja” }\end{array}$ & $\begin{array}{c}\text { Ponekad me } \\
\text { pozdravljaju sa } \\
\text { „zdravo”, a } \\
\text { ponekad sa ,dobro } \\
\text { jutro / dobar dan” / } \\
\text { „do viđenja” }\end{array}$ & $\begin{array}{l}\text { Nešto } \\
\text { drugo }\end{array}$ & Ukupno \\
\hline Vaspitna & Jaslena grupa & 1 & 11 & 21 & 2 & 35 \\
\hline grupa & Mlađa obdanišna grupa & 1 & 5 & 16 & 0 & 22 \\
\hline & Srednja obdanišna grupa & 3 & 8 & 16 & 0 & 27 \\
\hline & Starija obdanišna grupa & 0 & 11 & 6 & 0 & 17 \\
\hline & $\begin{array}{l}\text { Mešovita obdanišna } \\
\text { grupa }\end{array}$ & 0 & 6 & 11 & 0 & 17 \\
\hline & $\begin{array}{l}\text { Pripremna predškolska } \\
\text { grupa }\end{array}$ & 0 & 13 & 21 & 0 & 34 \\
\hline Ukupno & & 5 & 54 & 91 & 2 & 152 \\
\hline
\end{tabular}

Na osnovu dobijenih rezultata, uočava se da deca, bez obzira na uzrast, odnosno vaspitnu grupu, pozdravljaju svoje vaspitače i na formalan i na neformalan način (v. Tabela 3), što, najpre, govori o visokom stepenu bliskosti $i$ solidarnosti među sagovornicima. Pretpostavljamo da je uzrok neformalnog pozdravljanja i stav odraslih članova porodice, a pre svega roditelja, prema modelu pozdravljanja koje dete razvija. Dakle, međusobno pozdravljanje, prema rezultatima istraživanja, ne zavisi mnogo od uzrasta dece, već je tu prisutno više faktora. Rezultati istraživanja pokazuju da se deca, osim ponuđenih verbalnih formi pozdravljanja, sa svojim vaspitačima pozdravljaju i pomoću neverbalnih sredstava (v. Tabela 4).

Tabela 4. Najčešća neverbalna sredstva pozdravljanja među decom u predškolskoj ustanovi

\begin{tabular}{lcc}
\hline Neverbalna sredstva pozdravljanja & $\mathrm{f}$ & $\%$ \\
\hline Podizanje ruke ili mahanje & 62 & 40.8 \\
Zagrljaj & 52 & 34.2 \\
Poljubac & 1 & .7 \\
Klimanje glavom & 4 & 2.6 \\
Podizanje ruke, mahanje i zagrljaj & 24 & 15.8 \\
Zagrljaj i poljubac & 3 & 2.0 \\
Podizanje ruke, mahanje i poljubac & 1 & .7 \\
Nešto drugo & 5 & 3.3 \\
\hline Ukupno & 152 & 100.0 \\
\hline
\end{tabular}

Rezultati istraživanja pokazuju da su najčešća neverbalna sredstva pozdravljanja vaspitača osmeh i zagrljaj. Ne treba zanemariti i međusobno pozdravljanje dece pomoću neverbalnih sredstava. Analizom rezultata istraživanja, došlo se do saznanja da se deca predškolskog uzrasta najčešće međusobno pozdravljaju podizanjem ruke ili mahanjem (40,8\%), a najređe je zastupljen poljubac $(0,7 \%)$ ( $v$. Tabela 4$)$. Samo zagrljaj ili zagrljaj uz podizanje ruke i mahanje su takođe zastupljeni kao načini neverbalnog pozdravljanja među decom predškolskog uzrasta. Poljubac kao neverbalno sredstvo pozdravljanja zastupljeno je na starijem školskom uzrastu. 
Zanimalo nas je pomoću kojih jezičkih sredstava (izraza i etiketa) deca oslovljavaju svoje vaspitače, te smo odgovor tražili pomoću pitanja: Na koji način Vas deca oslovljavaju? Najviše vaspitača (40,8\%) odgovorilo je da ih deca oslovljavaju imenom, dok se samo $32 \%$ njih izjasnilo da ih deca oslovljavaju rečju „vaspitaču/vaspitačice”. U 11,8\% slučajeva deca svoje vaspitače oslovljavaju i rečju „,vaspitačice i imenom” (v. Tabela 5). Rezultati našeg istraživanja veoma su slični rezultatima istraživanja do kojih su došli istraživači i pre više decenija u predškolskim ustanovama (v. Vasić, 1979; Žilberg i Savić, 1982), što nam govori da se način oslovljavanja vaspitača nije promenio.

Tabela 5. Načini oslovljavanja vaspitača u predškolskim ustanovama

\begin{tabular}{lcc}
\hline Način oslovljavanja vaspitača & $f$ & $\%$ \\
\hline Imenom & 62 & 40.8 \\
Nadimkom & 20 & 13.2 \\
Rečju ,vaspitačice/vaspitaču” & 50 & 32.9 \\
Rečju ,vaspitačice” i imenom & 18 & 11.8 \\
Nešto drugo & 2 & 1.3 \\
\hline Ukupno & 152 & 100.0 \\
\hline
\end{tabular}

Rezultati našeg istraživanja takođe su pokazali da se ponekad od dece može čuti kolokvijalni izraz „vaspi” kao skraćena verzija reči „vaspitačice” za oslovljavanje vaspitača u predškolskim ustanovama. Da bismo imali jasniju sliku o načinu oslovljavanja vaspitača na različitim uzrastima, uporedili smo načine oslovljavanja vaspitača i vaspitne grupe u kojoj rade, te smo došli do zaključka da je u jaslenim grupama, mlađim i srednjim obdanišnim vaspitnim grupama dominantniji neformalni način oslovljavanja, odnosno oslovljavanje vaspitača imenom, dok u starijim i mešovitim obdanišnim grupama, kao i u pripremnim predškolskim grupama preovlađuje formalni način oslovljavanja vaspitača (v. Tabela 6).

Tabela 6. Način oslovljavanja vaspitača u zavisnosti od vaspitne grupe

\begin{tabular}{|c|c|c|c|c|c|c|c|}
\hline & & \multicolumn{5}{|c|}{ Na koji način deca Vas oslovljavaju? } & \multirow[b]{2}{*}{ Ukupno } \\
\hline & & Imenom & Nadimkom & $\begin{array}{c}\text { Rečju } \\
\text { „vaspitačice/ } \\
\text { vaspitaču” }\end{array}$ & $\begin{array}{c}\text { Rečju } \\
\text { „vaspitačice” i } \\
\text { imenom }\end{array}$ & $\begin{array}{l}\text { Nešto } \\
\text { drugo }\end{array}$ & \\
\hline \multirow{6}{*}{$\begin{array}{l}\text { Vaspitna } \\
\text { grupa }\end{array}$} & Jaslena grupa & 20 & 6 & 5 & 4 & 0 & 35 \\
\hline & $\begin{array}{l}\text { Mlađa obdanišna } \\
\text { grupa }\end{array}$ & 11 & 2 & 8 & 1 & 0 & 22 \\
\hline & $\begin{array}{l}\text { Srednja obdanišna } \\
\text { grupa }\end{array}$ & 15 & 3 & 5 & 4 & 0 & 27 \\
\hline & $\begin{array}{l}\text { Starija obdanišna } \\
\text { grupa }\end{array}$ & 5 & 4 & 6 & 1 & 1 & 17 \\
\hline & $\begin{array}{l}\text { Mešovita } \\
\text { obdanišna grupa }\end{array}$ & 3 & 2 & 9 & 2 & 1 & 17 \\
\hline & $\begin{array}{l}\text { Pripremna } \\
\text { predškolska grupa }\end{array}$ & 8 & 3 & 17 & 6 & 0 & 34 \\
\hline Ukupno & & 62 & 20 & 50 & 18 & 2 & 152 \\
\hline
\end{tabular}

U jaslenim i mlađim obdanišnim grupama je uobičajeno neformalno oslovljavanje (imenom, nadimkom), a u starijim grupama formalno oslovljavanje vaspitača. To potvrđuju i rezultati mnogih realizovanih istraživanja u predškolskim ustanovama (Kocher, 1976; Vasić, 1979; Jocić 
1981; Žilberg i Savić, 1982). Prema jednom istraživanju (up. Žilberg i Savić, 1982: 9) ističe se da za oslovljavanje starijih osoba deca uzrasta između dve i tri godine najčešće koriste vlastita imena, zatim termine za označavanje rodbinskih odnosa (mama, tata, deda, baba itd.), nadimke, i to najčešće upotrebljene u vokativu. Takođe, deca za oslovljavanje njima manje bliskih starijih osoba, ili osoba čije ime ne znaju, koriste reči (kontaktne forme, tj. Svoj protosistem za oslovljavanje, kako su ga autorke nazvale) kao što su: vidi, pogledaj, pazi, evo, eno, eto, ej i sl. „Uočljivo je da je spisak reči za oslovljavanje kod dece drugačiji od onog koji se daje za govor odraslih. Na spisku nema primera upotrebe titula (druže, gospodine, profesore itd.), niti primera upotrebe titule sa prezimenom (druže Petroviću), niti samog prezimena (Petroviću)" (Radovanović, 1979: 10). Osim navedenih primera, deca mlađeg (jaslenog) uzrasta neretko upotrebljavaju i sledeće forme oslovljavanja: 1) morfološki znak, tj. Nastavke za drugo lice jednine kod glagola u imperativu, prezentu, perfektu i futuru (npr. Napiši, daj), 2) zameničke forme Ti/Vi, 3) odsustvo jezičkog znaka - odsustvo sufiksa kod glagola, ali iz konteksta se može shvatiti da je reč o drugom licu jednine (up. Isto). U okviru našeg istraživanja, a povodom oslovljavanja vaspitača u predškolskim ustanovama, jedan ispitanik je naveo veoma zanimljivu situaciju sa svog radnog mesta upravo o načinu oslovljavanja u grupi dece sa kojom radi:

Često se događa da me deca, pretpostavljam zbog svakodnevnog celodnevnog boravka u vrtiću, oslove sa „tata”. Nekada primete pa se isprave, a nekad i ne primete, pa se komunikacija nastavi. Uglavnom ih ne ispravljam prilikom takvog oslovljavanja, jer je najčešće reč o lapsusu. Interesantno je da ni sam ne znam kako su deca počela da me zovu nadimkom. lako nisam pobornik takve vrste oslovljavanja dece prema vaspitačima, u našem vrtiću je uobičajno da sve članove kolektiva deca, pa čak i roditelji i drugi zaposleni, zovu imenom ili nadimkom. Svakako se to proširilo, pa čak i sa generacije na generaciju, kako kod dece tako i kod roditelja. $U$ jednom trenutku je došlo i do toga da me stručni saradnici i direktorka oslovljavaju nadimkom. Sve to je vremenom poprimilo i simpatičan oblik. Svakako, teško je ispraviti takav oblik oslovljavanja u okruženju gde to nije pravilo. Ipak, koleginica i ja smo prošle godine u pripremnoj predškolskoj grupi, smatrajući da je deci tog uzrasta veoma važno kao priprema za polazak u školu, odredili pravilo da nas deca oslovljavaju sa „vaspitaču / vaspitačice” što su posle izvesnog vremena uspešno usvojila, kao i da pozdrav isključivo bude „dobro jutro / dobar dan / do viđenja" (Anonimni ispitanik).

Ispitanici su dodatno upitani i kakvo je njihovo mišljenje o načinu oslovljavanja vaspitača u predškolskim ustanovama. Većina vaspitača (njih $67,8 \%$ ) se izjasnila da bi deca trebalo da ih oslovljava rečju „vaspitačice/vaspitaču”, što nam pokazuje da većina ispitanika više ceni formalni način oslovljavanja i smatra da je on poželjniji. Jedan broj ispitanika $(15,1 \%)$ smatra da bi deca predškolskog uzrasta trebalo da ih oslovljava imenom ili nadimkom, dok 9,7\% vaspitača nije sigurno kako bi deca trebalo da ih oslovljava (v. Tabela 7). Mali broj ispitanika (njih 7,9\%) smatra da bi deca trebalo da ih oslovljava onako kako sama žele u zavisnosti od njihovog uzrasta - ,ako je dete jaslenog ili mlađeg obdanišnog uzrasta, može oslovljavati vaspitača imenom ili nadimkom, a ukoliko je starijeg predškolskog uzrasta, trebalo bi oslovljavati svoje vaspitače rečju vaspitačice/vaspitaču" (Anonimni ispitanik).

Tabela 7. Mišljenje ispitanika o načinu oslovljavanja vaspitača u predškolskim ustanovama

\begin{tabular}{lcc}
\hline Mišljenja vaspitača & $f$ & $\%$ \\
\hline Deca treba da oslovljavaju vaspitače rečju ,,vaspitačice/vaspitaču” & 103 & 67.8 \\
Deca treba da oslovljavaju vaspitače ličnim imenom (prezimenom, nadimkom) & 23 & 15.1
\end{tabular}


Nisam siguran/na kako deca treba da oslovljavaju svoje vaspitače

Ispitanici su upitani ko bi trebalo da nauči decu pravilnom oslovljavanju vaspitača u predškolskoj ustanovi. Većina njih $(81,6 \%)$ smatra da su za to zaduženi i vaspitači i roditelji/zakonski staratelji. Tek $5,9 \%$ ispitanika smatra da su samo vaspitači odgovorni za vaspitanje dece, a kada je reč o oslovljavanju vaspitača u PU, dok $12,5 \%$ ispitanika smatra da su samo roditelji/zakonski staratelji za to zaduženi. Dakle, rezultati ukazuju na to da mišljenja ispitanika o načinu oslovljavanja vaspitača u predškolskim ustanovama nisu ujednačena. Činjenica je da je porodica primarni i najvažniji „,vaspitač” dece, dok je vaspitanje u vrtiću dopuna porodičnom vaspitanju. Porodica ima ključnu ulogu u životu deteta, ali se zajedničkim radom porodice i predškolske ustanove doprinosi boljem kognitivnom, fizičkom i zdravstvenom razvoju, razvoju psihičkih sposobnosti, kao i razvoju radnih navika, ali i snalaženju u životno-praktičnim situacijama. Predškolska ustanova je, takođe, veoma podsticajna za razvoj verbalne komunikacije kod dece, odnosno inventara reči I izraza za oslovljavanje I pozdravljanje (Jocić, 1981). Rečju, sve ono što porodica podstiče i razvija kod deteta, u vrtiću treba da se produbljuje, a sve ono što se u vrtiću razvija, porodica treba da podstiče. Zato je jedna od najvažnijih stvari u učenju i razvoju dece upravo saradnja između roditelja i vaspitača (v. Zakon o osnovama sistema obrazovanja i vaspitanja). I roditelji i vaspitači treba da pružaju pravilan govorni model detetu.

Nakon pitanja u vezi sa pozdravljanjem i oslovljavanjem, zanimalo nas je i na koji način se deca obraćaju svojim vaspitačima. Najveći broj vaspitača (85,5\%) je odgovorilo da im deca predškolskog uzrasta ne persiraju, a samo $9,9 \%$ vaspitača je odgovorilo da im deca persiraju. Takođe, 4,6\% vaspitača je istaklo da im neka deca persiraju, a neka ne (v. Tabela 8).

Tabela 8. Način na koji se deca obraćaju vaspitačima u predškolskim ustanovama

\begin{tabular}{lcc}
\hline Načini obraćanja vaspitačima & $f$ & $\%$ \\
\hline Deca mi persiraju & 15 & 9.9 \\
Deca mi ne persiraju & 130 & 85.5 \\
Neka deca mi persiraju, neka mi ne persiraju & 7 & 4.6 \\
\hline Ukupno & 152 & 100.0 \\
\hline
\end{tabular}

Razloge nepersiranja vaspitača valja objasniti zaključcima istraživanja koje je iznela Margareta Koher (Kocher, 1967) u svom radu. Naime, baveći se upotrebom zameničkih oblika obraćanja u srpskohrvatskom jeziku, na osnovu analize nekoliko književnih dela, autorka je u svom članku navela da se upotreba zamenice drugog lica množine Vi pri obraćanju jednoj osobi ne javlja pre sredine 17. veka. Objašnjenje za doslednu upotrebu $\mathrm{Ti}$, oblika kojim se izražava solidarnost i intimnost sagovornika u razgovoru, leži u obraćanju roditelja svojoj deci isključivo Ti formom, kao što je slučaj i sa decom čiji je maternji jezik srpski. U direktnom razgovoru sa odraslima dete ima mogućnost da čuje samo ovu formu obraćanja. Ono može da čuje Vi formu samo u indirektnom govoru - razgovoru roditelja sa starijim osobama, gostima, prijateljima, u kupovini itd. Isto tako, Koher zaključuje da je do pete ili šeste godine starosti upotreba forme Ti kod dece prikladna, kao da odrasli ne očekuju od male dece da pravilno upotrebljavaju Vi formu (up. Žilberg i Savić, 1982: 9). Dakle, formu Ti dete nauči i upotrebljava čim progovori, jer se svi detetu jaslenog i mlađeg predškolskog uzrasta obraćaju sa ti, te ono, imitirajući taj model, svakoga oslovljava sa ti, pa i svoje vaspitače. Kako Koher navodi, upotreba zamenice Vi zavisi od uticaja odraslih. Odrasli procenjuju kada dete treba da 
počne obraćanje odraslima sa Vi i kome će Vi najpre reći. „U procesu prelaska deteta iz uže, porodične sredine u širu, kakva je škola, roditelji se pojavljuju kao predstavnici kulturnog, socijalnog i jezičkog 'standarda' detetovog govornog ponašanja" (Isto: 14).

Kako bismo dobili jasniju sliku o tome da li postoji razlika u obraćanju vaspitačima na različitim uzrastima, pokušali smo da sagledamo način obraćanja dece vaspitačima u različitim vaspitnim grupama (v. Tabela 9).

Tabela 9. Način na koji se deca obraćaju vaspitačima u predškolskim ustanovama s obzirom na vaspitnu grupu

\begin{tabular}{llcccc}
\hline & & \multicolumn{3}{c}{ Na koji način Vam se deca obraćaju? } & \\
\cline { 3 - 5 } & & $\begin{array}{c}\text { Deca mi } \\
\text { persiraju }\end{array}$ & $\begin{array}{c}\text { Deca mi ne } \\
\text { persiraju }\end{array}$ & $\begin{array}{c}\text { Persiraju / ne } \\
\text { persiraju }\end{array}$ & Ukupno \\
\hline Vaspitna & Jaslena grupa & 3 & 32 & 0 & 35 \\
grupa & Mlađa obdanišna grupa & 1 & 21 & 0 & 22 \\
& Srednja obdanišna grupa & 2 & 22 & 3 & 27 \\
& Starija obdanišna grupa & 2 & 15 & 0 & 17 \\
& Mešovita obdanišna grupa & 1 & 14 & 2 & 17 \\
& Pripremna predškolska grupa & 6 & 26 & 2 & 34 \\
\hline Ukupno & & 15 & 130 & 7 & 152 \\
\hline
\end{tabular}

Na osnovu tabele možemo videti da je u svakoj vaspitnoj grupi, bez izuzetka, prisutniji neformalni način obraćanja dece svojim vaspitačima. Formalni način obraćanja je za nijansu prisutniji jedino u pripremnim predškolskim grupama. Deca mlađeg predškolskog uzrasta se u predškolskoj ustanovi obraćaju sa ti osoblju (posebno svojim vaspitačima) sa kojim se svakodnevno susreću. U godini pred polazak u školu neka deca će početi da upotrebljavaju formu Vi umesto Ti u razgovoru sa osobljem u ustanovi. Dete starijeg predškolskog uzrasta se svakodnevno suočava sa činjenicom da u jeziku postoje društvene uloge, kao i relativni društveni status u datoj prilici. Polazak u školu je poslednji trenutak za početak upotrebe $\mathrm{Vi}$ forme - đaci se učiteljima, nastavnicima, direktoru, pedagogu, psihologu i ostalom vannastavnom osoblju, a koje susreću na časovima ili odmorima, obraćaju obavezno sa Vi, odnosno obavezno treba da im persiraju (v. Elektronski izvor: Pravila ponašanja u školi). Kada pođe u školu, dete se nađe u situaciji „obrnutog autoriteta” u razgovoru sa učiteljem koga mora da oslovljava sa Vi, a koji mu govori ti. Dete će tu upotrebu kasnije preneti i na sve starije sa kojima razgovara (Kocher, 1967; prema Žilberg i Vasić, 1982: 10). Takođe, D. Kalogjera (Kalogjera, 1974) navodi podatak da roditelji intenzivno ispravljaju kod dece upravo „pogrešnu“ upotrebu forme Ti tamo gde bi po njihovoj proceni dete trebalo da upotrebi formu Vi.

Na pitanje kako bi trebalo deca da se obraćaju svojim vaspitačima u predškolskoj ustanovi, većina ispitanika $(63,2 \%)$ smatra da nema potrebe za formalnim obraćanjem vaspitačima od strane dece. Samo trećina (32,9\%) ispitanika smatra da bi deca trebalo da im persiraju, dok veoma mali broj ispitanika (njih 3,9\%) smatra da deca jaslenog i mlađeg predškolskog uzrasta ne treba da persiraju, dok deca starijeg predškolskog uzrasta treba da persiraju odraslima, odnosno svojim vaspitačima. Ako uporedimo mišljenja većine naših ispitanika o načinu obraćanja i oslovljavanja, možemo zaključiti da bi deca predškolskog uzrasta trebalo da ih oslovljavaju rečju „,vaspitaču/vaspitačice”, ali ne bi trebalo da im persiraju. 
Želeli smo da nam ispitanici u ovom istraživanju navedu i primere neobičnih i originalnih pozdrava i/ili neočekivano izabranih jezičkih sredstava u međusobnom verbalnom saobraćanju i oslovljavanju. Odgovori si brojni i zanimljivi: a) deca me ponekad pozdrave na stranim jezicima (engleskom, nemačkom, francuskom, španskom); b) deca me ponekad pozdrave imitirajući omiljenog lika iz crtanog filma; c) ponekad se međusobno pozdravimo stihovima pesama: Dobro jutro; č) međusobno se pozdravljamo pomoću pokretne igre Dobar dan; ć) ponekad nam se deca jave rečju Pozdrav!; d) ispred radne sobe nalaze se slike sa simbolima (za reči, rukovanje, zagrljaj, mahanje, ples, pljesak) koje deca biraju pokazujući na određeni simbol kao način pozdravljanja; dž) dete mi se obratilo sledećom rečenicom: „Moje srce želi nešto da Vam kaže... Dobro jutro!"; đ) Ponekad me deca pozdravljaju uz osmišljen pokret ili upotrebe lepu reč (npr. Do viđenja, volim Vas!); e) neka deca me pozdravljaju rečju Dovidence!; f) neka deca me pozdravljaju uz pomoć pantomime; g) deca me pozdravljaju uz pomoć sledećih neverbalnih sredstava: pesnicom o pesnicu, univerzalnom frazom „,baci pet”; h) većina dece u našem objektu vaspitače oslovljava rečju „,vaspi” (i to generacijama unazad); i) deci mlađeg predškolskog uzrasta je teško da izgovore „vaspitačice”, te se često može čuti od njih: ,tačice”, ,,ispitačice”, ,,vaspikačice” i sl.

Dakle, rezultati istraživanja vezani za pozdravljanje, obraćanje i oslovljavanje vaspitača u predškolskim ustanovama delimično su potvrdili našu drugu pomoćnu hipotezu da deca predškolskog uzrasta u pozdravljaju i oslovljavaju svojih vaspitača, kao i u obraćanju više koriste neformalne jezičke izraze i etikete. Naime, hipoteza je potvrđena samo kada je reč o neformalnom načinu obraćanja vaspitačima, dok u pozdravljanju i oslovljavanju deca koriste i formalna i neformalna jezička sredstva (izraze i etikete).

Pozdravljanje, oslovljavanje i obraćanje deci u predškolskim ustanovama.7 Da bismo otkrili na koji način vaspitači pozdravljaju decu, ispitanicima smo postavili pitanje: Na koji način Vi pozdravljate decu iz svoje vaspitne grupe? Oko dve trećine ispitanika odgovorilo je sa „dobro jutro / dobar dan / do viđenja", a oko trećine se izjasnilo da decu pozdravlja ponekad rečju „zdravo”, a ponekad sa „dobro jutro / dobar dan / do viđenja”. Samo 1,3\% ispitanika pozdravlja decu rečju „zdravo”. Na osnovu ovih rezultata istraživanja zaključuje se da je većina vaspitača više naklonjena formalnom načinu pozdravljanja. Da bi se dobila jasnija slika o mišljenju ispitanika u vezi sa načinom pozdravljanja dece, treba uporediti njihove odgovore sa vaspitnim grupama u kojima rade. Na osnovu upoređivanja rezultata istraživanja, došlo se do zaključka da je u svim vaspitnim grupama ipak više zastupljeni formalni način pozdravljanja dece (v. Tabela 10).

Tabela 10. Načini pozdravljanja dece u predškolskim ustanovama u zavisnosti od vaspitne grupe

\begin{tabular}{|c|c|c|c|c|c|}
\hline & & \multicolumn{3}{|c|}{ Na koji način Vi pozdravljate decu iz svoje vaspitne grupe? } & \multirow[b]{2}{*}{ Ukupno } \\
\hline & & $\begin{array}{c}\text { Rečju } \\
\text { „zdravo” }\end{array}$ & $\begin{array}{c}\text { Pozdravljam ih sa } \\
\text { „dobro jutro / } \\
\text { dobar dan” / ,do } \\
\text { viđenja” }\end{array}$ & $\begin{array}{c}\text { Ponekad ih pozdravljam } \\
\text { sa „,zdravo”, a ponekad } \\
\text { sa „,dobro jutro / dobar } \\
\text { dan” / „,do viđenja” }\end{array}$ & \\
\hline \multirow{3}{*}{$\begin{array}{l}\text { Vaspitna } \\
\text { grupa }\end{array}$} & Jaslena grupa & 0 & 21 & 14 & 35 \\
\hline & Mlađa obdanišna grupa & 0 & 13 & 9 & 22 \\
\hline & $\begin{array}{l}\text { Srednja obdanišna } \\
\text { grupa }\end{array}$ & 2 & 16 & 9 & 27 \\
\hline
\end{tabular}

\footnotetext{
7 U ovom istraživanju nisu ispitivane forme obraćanja deci u predškolskim ustanovama, jer je činjenica da se vaspitači deci u savremenom srpskom jeziku obraćaju isključivo Ti formom (ne persiraju deci). To pokazuju i rezultati ranijih istraživanja (v. Kocher, 1967; Žilberg i Savić, 1982).
} 


\begin{tabular}{lllll} 
Starija obdanišna grupa & 0 & 15 & 2 & 17 \\
$\begin{array}{l}\text { Mešovita obdanišna } \\
\text { grupa }\end{array}$ & 0 & 13 & 4 & 17 \\
$\begin{array}{l}\text { Pripremna predškolska } \\
\text { grupa }\end{array}$ & 0 & 27 & 7 & 34 \\
\hline Ukupno & 2 & 105 & 45 & 152 \\
\hline
\end{tabular}

Mnogi autori smatraju pozdrave ,formulama učtivosti” (Kristal, 1995: 52) ili formama učtivosti (v. Milosavljević, 2007). Kada je reč o načinu pozdravljanja u predškolskim ustanovama, u pravilnicima (v. Pravila ponašanja u predškolskoj ustanovi „Čarolija” Vršac dece, zaposlenih i roditelja: tačka 8 , član 49 ) je naglašeno da kontakt vaspitača (zaposlenih) sa roditeljima i strankama treba da bude u skladu sa pravilima poslovnog komuniciranja, te da se intimniji način pozdravljanja ne preporučuje. Takođe, naglašava se da zaposleni prvi pozdravlja stranku uz prijatan izraz lica i osmeh.

Osim oslovljavanja vaspitača od strane dece, koje smo razmatrali u radu, želeli smo da saznamo i kako vaspitači oslovljavaju decu iz svoje vaspitne grupe. Većina ispitanika $(81,6 \%)$ se izjasnila da decu oslovljava imenom, samo $2 \%$ njih najčešće oslovljava decu nadimkom, a njih $3,9 \%$ decu oslovljava hipokorističnim etiketama (rečima iz milošte): dušo, srce, mili/mila i sl. Hipokoristične etikete za oslovljavanje dece upotrebljavaju se u vokativu kako bi se iskazala emocionalna povezanost odraslog $\mathrm{i}$ deteta. Može se pretpostaviti da je ovim rečima u vokativu osnovna funkcija kontrola i/ili regulacija detetovog ponašanja (up. Jocić, 1981). „Vokativ služi za započinjanje razgovora, odabiranje sagovornika među nekoliko potencijalno prisutnih, zadržavanje sagovornikove pažnje u već započetom razgovoru, izražavanje želje ili zahteva da se sagovornik o nečemu informiše, te neke vidove kontrolisanja sagovornikovog ponašanja" (Žilberg i Savić, 1982: 11). Nasuprot tome, manji broj ispitanika (njih 11,8\%) izjasnio se da oslovljava decu na različite načine (i imenom, i prezimenom ili im tepa), a u zavisnosti od situacije i raspoloženja. Vaspitači su takođe upitani i kako oslovljavaju grupu dece. Na ovo pitanje je nešto više od polovine ispitanika (njih 57,9\%) odgovorilo da grupu dece oslovljava rečju „deco”, a trećina ispitanika (30,9\%) se izjasnila da ih oslovljava ponekad rečju „deco”, a ponekad rečju „drugari”, što je označeno semantički nespecifično obeleženim jezičkim sredstvima (v. Radovanović, 1986).

Rezultati istraživanja vezani za pozdravljanje i oslovljavanje dece u predškolskim ustanovama potvrdili su našu treću pomoćnu hipotezu kojom smo pretpostavili da vaspitači više koriste neformalne jezičke izraze i etikete kada oslovljavaju decu, dok za pozdravljanje koriste formalne jezičke izraze.

Mišljenje i stavovi vaspitača o načinu komunikacije u predškolskim ustanovama s obzirom na mesto u kome rade, pol i dosadašnje radno iskustvo. Analiza rezultata istraživanja pokazuje da ispitanici u manjim mestima (manjim gradovima i opštinama - njih 32,9\%) smatraju da nema potrebe za formalnim pozdravljanjem i oslovljavanjem vaspitača od strane dece, kao i persiranjem (obraćanjem) vaspitačima, jer se, ,uglavnom svi međusobno poznaju ili druže”.

Upoređujući odgovore ispitanika o međusobnom pozdravljanju, obraćanju i oslovljavanju vaspitača i dece u predškolskim ustanovama s obzirom na pol, uočeno je da su mišljenja među ispitanicima muškog pola podeljena kada je reč o pozdravljanju i oslovljavanju, ali da oni dele isto mišljenje, bez obzira na radni staž i uzrast dece sa kojima rade kada je reč o obraćanju ispitanici muškog pola smatraju da nema potrebe da im deca predškolskog uzrasta persiraju. 
Ispitanici ženskog pola imaju različite stavove o načinu primene svih razmatranih formi komunikativnih diskursa u predškolskim ustanovama.

Kod ispitanika koji imaju radni staž do trideset godina preovladava stav da nema potrebe za formalnim obraćanjem, dok ispitanici koji rade preko trideset godina smatraju da je potrebno da im deca persiraju. Kada smo uporedili odgovore ispitanika o vaspitanju dece u vezi sa načinom komunikacije u predškolskoj ustanovi i sa godinama njihovog radnog staža, došli smo do sledećih rezultata istraživanja: među vaspitačima koji smatraju da su lično najviše odgovorni za vaspitanje dece, kada je reč o oslovljavanju, jesu oni koji imaju do pet godina radnog staža, dok među vaspitačima koji imaju između deset i dvadeset godina radnog iskustva ima najviše onih koji smatraju da su za to odgovorni ili samo roditelji/zakonski staratelji dece, ili i vaspitači i roditelji/zakonski staratelji. Dakle, mišljenja ispitanika su podosta podeljena i razlikuju se prema nezavisnim varijablama koje smo izdvojili, što potvrđuje našu četvrtu pomoćnu hipotezu.

Sticanje saznanja o temi pozdravljanja, obraćanja i oslovljavanja u predškolskim ustanovama. O temi pozdravljanja, obraćanja i oslovljavanja se može mnogo saznati i naučiti iz različitih izvora, kao što su knjige o kulturi govora, naučni i stručni časopisi, udžbenici, priručnici, radovi, bonton, seminari stručnog usavršavanja, projektne aktivnosti, stručne konferencije $i$ sl. Želeli smo da saznamo na koji način se vaspitači informišu, odnosno na koji način dolaze do saznanja na temu pozdravljanja, obraćanja i oslovljavanja u predškolskim ustanovama. Najviše ispitanika $(40,1 \%)$ je steklo saznanja o ovoj temi u okviru nastavnih sadržaja različitih predmeta - tokom formalnog obrazovanja ( $v$. Tabela 11), čime je potvrđena i naša poslednja, peta pomoćna hipoteza.

Tabela 11. Sticanje saznanja o temi pozdravljanja, obraćanja i oslovljavanja u predškolskim ustanovama

\begin{tabular}{lcc}
\hline Sa temom pozdravljanja, obraćanja I oslovljavanja u predškolskim ustanovama & $\mathrm{f}$ & $\%$ \\
upoznao/la sam se: & 61 & 40.1 \\
\hline Tokom formalnog obrazovanja (u okviru nastavnih sadržaja različitih predmeta) & 16 & 10.5 \\
Na seminarima stručnog usavršavanja & 3 & 2.0 \\
Tokom projektnih aktivnosti & 13 & 8.6 \\
Na stručnim skupovima, tribinama, konferencijama & 10 & 6.6 \\
Na sastancima stručnih aktiva & 16 & 10.5 \\
Čitanjem naučnih i/ili stručnih časopisa, udžbenika, priručnika idruge literature & $\varnothing$ & $\varnothing$ \\
Pretraživanjem sadržaja na internetu & 59 & 38.8 \\
Nikada se nisam posebno bavio/la ovom temom & 11 & 7.2 \\
Nešto drugo & &
\end{tabular}

Iz ove tabele se može videti da se nešto više od trećine ispitanika (38,8\%) nikada nije posebno bavilo ovom temom. Na internetske izvore se, konkretno za ove vidove komunikativnih diskursa, niko nije oslonio. Naposletku, bilo nam je veoma važno da otkrijemo mišljenje ispitanika i o standardizaciji pravila vezanih za međusobno pozdravljanje, obraćanje i oslovljavanje dece i vaspitača. Mišljenja praktičara, naših ispitanika su veoma različita, a ujedno i prihvatljiva (v. Tabela 12). 
Tabela 12. Mišljenje vaspitača o standardizaciji pravila vezanih za međusobno pozdravljanje, obraćanje i oslovljavanje dece i vaspitača

\begin{tabular}{lcc}
\hline Mišljenje vaspitača & $f$ & $\%$ \\
\hline Treba standardizovati, odnosno utvrditi jedino prihvatljivu formu pozdrava, & 20 & 13.2 \\
obraćanja i oslovljavanja u kontekstu predškolske ustanove & & 42.1 \\
Treba ostaviti na volju učesnika/ca u komunikaciji, a imajući u vidu uzrast dece & 64 & 44.7 \\
Postaviti standardne okvire, truditi se i podsticati komunikatore da se ti okviri & 68 & 152 \\
poštuju, ne umanjujući pritom slobodu i kreativnost vaspitača, pogotovo dece & 100.0 \\
\hline Ukupno & & 4 \\
\hline
\end{tabular}

Najveći broj ispitanika (njih 44\%) smatra da je potrebno postaviti standardne okvire o međusobnom pozdravljanju, oslovljavanju i obraćanju vaspitača i dece u predškolskim ustanovama, ali da se pritom ne umanji sloboda i kreativnost izražavanja ni vaspitača ni dece. Rezultati istraživanja vezani za standardizaciju pravila o komunikativnim diskursima među decom i vaspitačima potkrepljuju naše mišljenje o potrebi za postavljanjem standardnih okvira u pravilnicima koje mora da poseduje svaka predškolska ustanova u R Srbiji, a donetih na osnovu Zakona o predškolskom vaspitanju i obrazovanju.

\section{Zaključna razmatranja}

Rezultati našeg istraživanja potvrdili su većinu pomoćnih hipoteza (prvu, treću, četvrtu i petu), dok je druga delimično potvrđena. Naime, naši ispitanici su potvrdili da predškolske ustanove nemaju pravilnik u kome su određena pravila o komunikativnim diskursima međusobnom pozdravljanju, oslovljavanju i obraćanju. Pravila se, najčešće, postavljaju interno, unutar svake predškolske ustanove. Dobijeni rezultati, takođe, pokazuju da većina dece ne persira svojim vaspitačima, dok u pozdravljanju i oslovljavanju vaspitača koriste i formalne i neformalne jezičke izraze i etikete, bez obzira na uzrast vaspitne grupe. Rezultati dobijeni u ovom istraživanju odgovaraju rezultatima iz ranije sprovedenih istraživanja na ovu temu u predškolskim ustanovama (up. Vasić, 1979; Jocić, 1981; Žilberg i Savić, 1982) koji pokazuju da većina dece na ranom predškolskom uzrastu svoje vaspitače najčešće oslovljavaju imenom, a ne rečju ,vaspitaču/vaspitačice”.

Vaspitači više koriste neformalne jezičke izraze i etikete kada oslovljavaju decu, dok za pozdravljanje koriste formalne jezičke izraze. Mišljenja ispitanika/vaspitača se dosta razlikuju o načinima i formama pozdravljanja, obraćanja i oslovljavanja u predškolskim ustanovama s obzirom na mesto u kome rade, pol i godine radnog staža, te nas ne iznenađuje ni njihov stav da je potrebno postaviti standardne okvire o međusobnom pozdravljanju, oslovljavanju $\mathrm{i}$ obraćanju vaspitača i dece u predškolskim ustanovama, ali da se, pritom, ne umanji sloboda i kreativnost izražavanja ni vaspitača ni dece. Dakle, praktičari su potvrdili teorijske pretpostavke o potrebi za standardizacijom pravila komunikativnog ponašanja u predškolskim ustanovama.

S jedne strane, rezultati istraživanja pokazuju da je najviše ispitanika o temi pozdravljanja, oslovljavanja i obraćanja steklo saznanja u okviru nastavnih sadržaja različitih predmeta tokom formalnog obrazovanja, a, s druge strane, više od trećine njih nikada se nije posebno bavilo ovom temom. Takođe, u ovom istraživanju smo došli i do saznanja da više od dve trećine ispitanika ipak smatra kako bi deca predškolskog uzrasta trebalo da ih oslovljavaja na formalan način - rečju „vaspitaču/vaspitačice”, ali da ne bi trebalo da im persiraju. S obzirom na prethodno iznete rezultate u kojima se jasno vide različiti stavovi i mišljenja među 
ispitanicima o ovoj temi, primetno je da postoji izražena potreba za postavljanjem standardnih okvira kada je reč o prihvatljivim formama pozdravljanja, obraćanja i oslovljavanja među vaspitačima i decom u kontekstu predškolske ustanove, čime je potvrđena naša osnovna hipoteza. Izvesno je da treba obratiti posebnu pažnju formama komunikativnih diskursa i načinima njihove primene u predškolskim ustanovama i na seminarima stručnog usavršavanja, stručnim skupovima, tribinama, konferencijama, na sastancima stručnih aktiva, te da se vaspitači više posvete istraživanju i upotrebi naučnih i/ili stručnih časopisa, udžbenika, priručnika i druge literature o ovoj temi.

Simulacijom raznih životno-praktičnih situacija u radu sa decom, kao i organizacijom raznovrsnih jezičkih igara u različitim komunikativnim diskursima, gde su zastupljene učtive forme pozdravljanja, oslovljavanja i obraćanja, može se vežbati raznovrsna upotreba govora u svakodnevnim životnim i igrovnim situacijama ${ }^{8}: 1$ ) igre pozdravljanja (npr. Igra Pozdravi me dete kojem vaspitač baci loptu ili doda neku igračku treba da uputi „,pozdrav” verbalno i/ili neverbalno; ostala deca treba da na isti način ponove pozdrav); 2) igre obraćanja (npr. Igra obraćanja Lepi maniri - vaspitač organizuje „Pijenje čaja”, tako što poziva decu da sednu za sto i servira im čaj, a pijenje čaja prate pitanja i odgovori: Da li biste želeli još čaja? - Da, molim; Ne, hvala; Hvala lepo...); 3) igre oslovljavanja (npr. Igra oslovljavalja Oslovljavamo čudna bića od dece se zatraži da se obrate čudnim bićima sa slike uz pozdravljanje: Dobar dan, gospodine Šeširku! Laku noć, gospođo Sjajnozvezdice!).

Verujemo da će ovo istraživanje motivisati dalja istraživanja ispitivane teme ne samo iz perspektive vaspitača, već i pedagoga, psihologa, psiholingvista i sociologa, a da će u narednom periodu upravni odbori predškolskih ustanova donositi konkretnija pravila ponašanja u kojima će biti postavljeni standardni okviri o prihvatljivim formama pozdravljanja, obraćanja i oslovljavanja među vaspitačima i decom, imajući u vidu uzrast dece i vaspitne grupe.

\section{Literatura i izvori:}

Aleksandrovic, M., Savic, S. i Stanojevic, D. (2012). Pozdravljanje i oslovljavanje u romskom jeziku. [PERSIRIPEN THAJ ABHIVADANISARIPE ANDE ROMINI CHIB] U: D. Stanojevic i S. Savic (prir.), Iz riznice multijezicke Vojvodine: Zbornik Pedagoskog zavoda Vojvodine, 8: Oslovljavanje i pozdravljanje u savremenim jezicima nacionalnih zajednica u Vojvodini. Novi Sad: Pedagoski zavod Vojvodine, 10-32.

Andric, E. (2012). Pozdravljanje i oslovljavanje u madarskom jeziku. U: D. Stanojevic i S. Savic (prir.), Iz riznice multijezicke Vojvodine: Zbornik Pedagoskog zavoda Vojvodine, 8: Oslovljavanje i pozdravljanje u savremenim jezicima nacionalnih zajednica u Vojvodini. Novi Sad: Pedagoski zavod Vojvodine, 33-49.

Baumeister et al. (2003). „Does High Self-Esteem Cause Better Performance, Interpersonal Success, Happiness, or Healthier Lifestyles?" Psychol Sci Public Interest. https://doi.org/10.1111/1529-1006.01431

Baumeister, R. F., Dale, K., \& Sommer, K. L. (1998). Freudian defense mechanisms and empirical findings in modern social psychology: Reaction formation, projection, displacement, undoing, isolation, sublimation, and denial. Journal of Personality, 66, 1081-1124. https://doi.org/10.1111/1467-6494.00043

\footnotetext{
8 Više o ovim igrama videti u: Đorđev i Kerekeš Bisak, 2017: 86-102; Đorđev, 2018: 82-88.
} 
Bonton - pravila lepog ponasanja. Preuzeto sa portala Beleske / Magazin / Lifestyle: https://beleske.com/bonton-pravila-lepog-ponasanja/, objavljeno: 12. 11. 2012, datum preuzimanja: 8.3. 2020.

Braun, F. (1988). Terms of Address: Problems of patterns and usages in various languages and cultures. Berlin-New York: Mouton de Gruyter.

Brown, R., \& Gilman, A. (1972). The Pronouns of Power and Solidarity. In: Giglioli, P. P. (ed.) Language and Social Context. London: Penguin, 252-282.

Dotlic, Lj. i Kamenov, E. (1996). Književnost u decjem vrticu. Novi Sad: Zmajeve decje igre, Odsek za pedagogiju Filozofskog fakulteta. [Izvor na cirilici.]

Dordev, I. (2016). The orthographic norm in secondary school students' written assignments, Research in Pedagogy. Academy of Education Belgrade, Preschool Teacher Training College Mihailo Palov, Vrsac. UDC: 37.025 ISSN 2217-7337, 43-54. CrossRef, PILA Member: Under the mark CrossRef, Indexed in: COBISS (SR), Categorized by: Ministry of Education, Science and Technological Development, EBSCO, Available at Journal\&e-Package Service, SCIndeks - Serbian Citation Index, Driven by doi: 10.17810/2015.22.

Dordev, I., Kelemen Milojevic, Lj. i Dordevic, M. (32017). Praktikum za srpski jezik. Vrsac: Visoka skola strukovnih studija za vaspitace „Mihailo Palov”. ISBN 978-86-7372-246-7; COBISS.SR-ID 315637255. [Izvor na cirilici.]

Dordev, I. (2018). Lepa rec. Vrsac: Visoka skola strukovnih studija za vaspitace „Mihailo Palov". [Izvor na cirilici.]

Dordev, I. i Kerekes Bisak, I. (2017). (Jezicke) igre i igrolike aktivnosti u razlicitim komunikativnim diskursima. Skolski cas, XXXIII/2, 86-102.

Hajmz, D. (1980). Etnografija komunikacije. Beograd: BIGZ - Biblioteka XX vek.

Ivic, M. (1989). Neka zapažanja o rodu i broju u srpskohrvatskom jeziku. Južnoslovenski filolog, XLV. Beograd, 27-44. [Izvor na cirilici.]

Jocic, M. (1981). Osobine jezickog komuniciranja vaspitaca sa decom predskolskog uzrasta. Prilozi proucavanju jezika. Novi Sad: Filozofski fakultet, 17, 103-117. [Prestampano uz manje modifikacije pod naslovom: Osobine jezickog komuniciranja vaspitaca sa decom predskolskog uzrasta. U: Mirjana Jocic, Jezik, komunikacija, razvoj. Novi Sad: Dnevnik, Novi Sad, 206, 89-110.]

Jocic, M. (2011). Oslovljavanje i obracanje. U: V. Vasic i G. Strbac (ur.), Lingvisticke sveske 9: Govor Novog Sada - Sveska 2: Morfosintaksicke, leksicke i pragmaticke osobine. Novi Sad: Filozofski fakultet, 297-346. [Izvor na cirilici.]

Jovicic, J. (2012). Strategije i taktike uspesnih žena 19. Veka: na tragu zlatne decenije srpskonemackih interkulturnih veza: Mina i Talfj u privatnoj prepisci. Novi Sad: Futura publikacije.

Kalogjera, D. (1974). U prilog pojmu komunikativne kompetencije. Kultura, 25, 138-146.

Kasic, J. (1987). Neke pojave u vezi sa oslovljavanjem. Tragom Vukove reci. Novi Sad: Matica srpska, 200-207. [Izvor na cirilici.]

Kelemen Milojevic, Lj. (2021). Razvoj govora u predskolskoj ustanovi. Vrsac: Visoka skola strukovnih studija za vaspitace „Mihailo Palov”. [Izvor na cirilici.]

Kocher, M. (1967). Second Person Pronouns in Serbo-Croatian. Language, 43/3, 725-741. https://doi.org/10.2307/411813

Kristal, D. (21995). Enciklopedijski recnik moderne lingvistike. Beograd: Nolit.

Markov-Spanovic, M. (2012). Pozdravljanje i oslovljavanje vojvodanskih Hrvata - refleksija identiteta. U: D. Stanojevic i S. Savic (prir.), Iz riznice multijezicke Vojvodine: Zbornik Pedagoskog zavoda Vojvodine, 8: Oslovljavanje i pozdravljanje u savremenim jezicima nacionalnih zajednica u Vojvodini. Novi Sad: Pedagoski zavod Vojvodine, 50-83.

Milosavljevic, B. (2007). Forme uctivosti u srpskom jeziku. Beograd: Uciteljski fakultet. [Izvor na cirilici.] 
Ozer, K. (2011). Pronominalne forme sa funkcijom oslovljavanja u nemackom i srpskom jeziku i promena modusa. U: Savremena proucavanja jezika i književnosti: zbornik radova sa II naucnog skupa mladih filologa Srbije, knj. 1, 403-414. Kragujevac: Filum Filoloskoumetnicki fakultet. [Izvor na cirilici.]

Petrovic, J. ( $\left.{ }^{8} 2019\right)$. Bonton. Beograd: Kreativni centar.

Polovina, V. (1983). Upotreba jednine i množine licnih zamenica u obracanju sagovornika u srpskohrvatskom jeziku. Naucni sastanak slavista u Vukove dane 13/1, 185-195.

Pravila ponasanja dece, zaposlenih i roditelja u predskolskoj ustanovi „Majski cvet” u Velikom Gradistu. Preuzeto sa http://vrticvg.edu.rs/akta/pravilaponasanja.pdf, objavljeno: 5. 4. 2018, datum preuzimanja: 3. 3. 2020. [Izvor na cirilici.]

Pravila ponasanja u predskolskoj ustanovi „Carolija” Vrsac dece, zaposlenih i roditelja. Preuzeto sa http://www.pucarolija.com/wp-content/uploads/2011/08/Pravilaponasanja -uustanovi.pdf, objavljeno: 2. 12. 2015, datum preuzimanja: 3. 3. 2020. [Izvor na cirilici.]

Pravila ponasanja u predskolskoj ustanovi „Cukarica”. Preuzeto sa http://pucukarica.rs/, objavljeno: 20. 8. 2015, datum preuzimanja: 3. 3. 2020. [Izvor na cirilici.]

Pravila ponasanja u skoli. Preuzeto sa portala Žena / Blic: https://zena.blic.rs/porodica/ pravilaponasanja-u-skoli/bev1nsq, objavljeno: 26. 4. 2017, datum preuzimanja: 4.3. 2020.

Pravopis srpskoga jezika (izmenjeno i dopunjeno ekavsko izdanje). Pravila i njihovi osnovi. Recnik uz pravopis, 2010. Redakcija izmenjenog i dopunjenor izdanja: M. Pižurica (glavni redaktor), M. Desic, B. Ostojic, Ž. Stanojcic. Novi Sad: Matica srpska. [Izvor na cirilici.]

Radovanovic, M. (1979). Sociolingvistika. Beograd: Beogradski izdavacki zavod.

Radovanovic, M. (1986). Sociolingvistika. Novi Sad: Književna zajednica Novog Sada; Dnevnik.

Savanov, M. i Basic Palkovic, N. (2012). Oslovljavanje i pozdravljanje kod Bunjevaca. U: D. Stanojevic i S. Savic (prir.), Iz riznice multijezicke Vojvodine: Zbornik Pedagoskog zavoda Vojvodine, 8: Oslovljavanje i pozdravljanje u savremenim jezicima nacionalnih zajednica u Vojvodini. Novi Sad: Pedagoski zavod Vojvodine, 84-98.

Savic, S. i Stanojevic, D. (2012). Oslovljavanje i pozdravljanje u srpskom jeziku: pregled istraživanja (1979-2011). U: D. Stanojevic i S. Savic (prir.), Iz riznice multijezicke Vojvodine: Zbornik Pedagoskog zavoda Vojvodine, 8: Oslovljavanje i pozdravljanje u savremenim jezicima nacionalnih zajednica u Vojvodini. Novi Sad: Pedagoski zavod Vojvodine, 99-152.

Spariosu L. i Janjic, I. (2012). Kratak prikaz oslovljavanja, pozdravljanja i obracanja u savremenom rumunskom jeziku. U: D. Stanojevic i S. Savic (prir.), Iz riznice multijezicke Vojvodine: Zbornik Pedagoskog zavoda Vojvodine, 8: Oslovljavanje i pozdravljanje u savremenim jezicima nacionalnih zajednica u Vojvodini. Novi Sad: Pedagoski zavod Vojvodine, 153-167.

Standardi za razvoj i ucenje dece ranih uzrasta $u$ Srbiji. Preuzeto sa https://www.udruzenjepedijatara.rs/pdf/OPSTA/2_Standardi_za_razvoj_i_ucenje_de ce_ranih_uzrasta_u_Srbiji.pdf, objavljeno 2012, datum preuzimanja: $4 \cdot 3 \cdot 2020$.

Stanojevic, D. (2012). Predgovor. U: D. Stanojevic i S. Savic (prir.), Iz riznice multijezicke Vojvodine: Zbornik Pedagoskog zavoda Vojvodine, 8: Oslovljavanje i pozdravljanje u savremenim jezicima nacionalnih zajednica u Vojvodini. Novi Sad: Pedagoski zavod Vojvodine, 7-9.

Sarko-Golubovic N. (2012). Oslovljavanje i pozdravljanje u savremenom jeziku ukrajinske nacionalne zajednice u Vojvodini. U: D. Stanojevic i S. Savic (prir.), Iz riznice multijezicke Vojvodine: Zbornik Pedagoskog zavoda Vojvodine, 8: Oslovljavanje i pozdravljanje u savremenim jezicima nacionalnih zajednica u Vojvodini. Novi Sad: Pedagoski zavod Vojvodine, 188-211.

Sipka, M. (2008). Kultura govora. Novi Sad: Prometej. [Izvor na cirilici.] 
Vasic, I. (1979). Govorno ponasanje predstavnika savremenog srpskohrvatskog jezika u situaciji obracanja. Prilozi proucavanju jezika 15. Novi Sad: Filozofski fakultet, 57-70.

Vasic, V. (1979). Tipovi oslovljavanja odrasle osobe u govoru dece predskolskog uzrasta. Godisnjak Saveza drustava za primenjenu lingvistiku Jugoslavije. III: 175-180.

Vasic, V. (1983). Govor sestre sa bratom (deo: Oslovljavanje i samooslovljavanje). Institut za južnoslovenske jezike. Novi Sad: Filozofski fakultet, 110-131.

Veljkovic Stankovic, D. i Dordev, I. (2018). Pismenost novog doba iz perspektive buducih vaspitaca i nastavnika. Primenjena lingvistika, 19, 7-22. https://doi.org/10.18485/ primling.2018.19.1 [Izvor na cirilici.]

Vukovic, G. (1980). Nazivi za obeležavanje srodnika (na materijalu srpskohrvatskog, slovackog, madarskog i nemackog jezika). Kontrastivna jezicka istraživanja, 1. Novi Sad: Filozofski fakultet, 253-265.

Zakon o osnovama sistema obrazovanja i vaspitanja („Sl. glasnik RS”, br. 88/2017, 27/2018 - dr. zakon, 10/2019, 27/2018 - dr. zakon i 6/2020). Preuzeto iz pravne baze Paragraf Lex, dostupno na adresi: https://www.paragraf.rs/propisi_download/zakon_o_ osnovama_sistema_obrazovanja_i_vaspitanja.pdf, objavljeno: 6. 2020, datum preuzimanja: 3.3. 2020.

Zakon o predskolskom vaspitanju i obrazovanju („Sl. glasnik RS”, br. 18/2010, 101/2017, 113/2017 - dr. zakon, 95/2018 - dr. zakon i 10/2019). Preuzeto iz pravne baze Paragraf Lex, dostupno na adresi: https://www.paragraf.rs/propisi/zakon-o-predskolskomvaspitanju-i-obrazovanju.html, datum preuzimanja: 3. 12. 2021.

Žiberg, I. i Savic, S. (1982). Neki aspekti oslovljavanja u govoru dece predskolskog uzrasta. Prilozi proucavanju jezika 18, 5-26. Preuzeto sa: https://www.scribd.com/doc/271009697/Neki-Aspekti-Oslovljavanja-u-Govoru-DecePredskolskog-Uzrasta, datum preuzimanja: 8.1. 2020.

\section{Biografske beleške autora:}

Ljiljana Kelemen Milojević je doktor nauka - metodike nastave. Rođena je 1985. godine u Vršcu, gde je završila osnovnu i srednju školu. Diplomirala je i doktorirala na Učiteljskom fakultetu Univerziteta u Beogradu. Profesor je strukovnih studija na Visokoj školi strukovnih studija za vaspitače „Mihailo Palov” u Vršcu. Jedan je od osnivača Jezičkog kluba Visoke škole, član je Matice srpske, Društva predmetnih didaktičara Srbije i Organizacionog odbora u okviru Međunarodnog naučnog skupa o darovitima na Visokoj školi u Vršcu. Aktivno učestvuje na domaćim i međunarodnim projektima, stručnim i naučnim skupovima i konferencijama, pretežno međunarodnog karaktera. Autor je i realizator više akreditovanih seminara stručnog usavršavanja nastavnika, vaspitača i stručnih saradnika Zavoda za unaređivanje obrazovanja i vaspitanja i Pedagoškog zavoda Vojvodine. Do sada je u autorstvu ili koautorstvu objavila jedanaest udžbenika i oko pedeset naučnih i stručnih radova.

Milica Petrović je rođena 1996. u Požarevcu. Diplomirala je na Visokoj školi strukovnih studija za vaspitače „Mihailo Palov” u Vršcu, a u istoj ustanovi je završila i specijalističke i master strukovne studije. Bila je članica Jezičkog kluba i Hora Visoke škole, a tokom specijalističkih strukovnih studija boravila je jedan semestar u Jašiju, u Rumuniji, u okviru Erasmus + programa razmene studenata, gde je uspešno završila početni kurs rumunskog jezika. Učestvovala je na Međunarodnoj konferenciji studenata pod nazivom „Savremeni izazovi u vaspitanju i obrazovanju - didaktički aspekti" 2017. godine, a objavila je radove pod nazivom: 1) „Kako da budete odličan slušalac - usavršavanje veštine slušanja kao osnov uspešne komunikacije” u Zborniku radova „Komunikacija u multikulturalnoj sredini i vaspitnoobrazovnom radu” 2018. godine; 2) „Work with children with special need - problems with 
speech development - stuttering” u naučnom zborniku „Learning solutions in medical higher education - an interdisciplinary approach” 2019. godine i 3) „Didaktički instrumentarijum u integrisanom kurikulumu u vrtiću" u Zborniku radova povodom III međunarodne konferencije pod nazivom "Savremeni izazovi u didaktici i obrazovanju” 2020. godine. Zaposlena je u Predškolskoj ustanovi „Majski cvet” u Velikom Gradištu.

\section{PRILOG}

\section{Upitnik za vaspitače}

Pol:

Naziv predškolske ustanove: Mesto:

Radno iskustvo:

Vaspitna grupa sa kojom radite:
1. Ženski
2. Muški
a) a) Manje od 1 godine;
b) 1-5 godina;
c) 5-10 godina;
d) 10-20 godina;
e) 20-30 godina;
f) preko 30 godina.
a) a) mlađa/srednja/starija jaslena grupa;
b) mlađa obdanišna grupa;
c) srednja obdanišna grupa;
d) starija obdanišna grupa;
e) mešovita obdanišna grupa;
f) pripremna predškolska grupa.

1. Da li u Vašoj predškolskoj ustanovi postoji pravilnik u kome su određena pravila o komunikativnim diskursima (međusobnom pozdravljanju, oslovljavanju i obraćanju)?
a) Naša predškolska ustanova nema pravilnik u kome su određena pravila o komunikativnim diskursima;
b) naša predškolska ustanova ima pravilnik u kome su određena pravila o komunikativnim diskursima;
c) ne znam / nisam siguran/na.

2. Na koji način Vi pozdravljate decu iz svoje vaspitne grupe?
a) Pozdravljam ih rečju ,zdravo";
b) pozdravljam ih sa „dobro jutro / dobar dan” / „,do viđenja”;
c) ponekad ih pozdravljam sa „zdravo”, a ponekad sa „dobro jutro / dobar dan” / „do viđenja";
d) nešto drugo: 
3. Na koji način deca Vas pozdravljaju?
a) Pozdravljaju me rečju ,zdravo";
b) pozdravljaju me sa „,dobro jutro / dobar dan” / „do viđenja”;
c) ponekad me pozdravljaju sa „zdravo”, a ponekad sa „,dobro jutro / dobar dan” / „do viđenja";
d) nešto drugo:

4. Najčešća neverbalna sredstva pozdravljanja među decom u predškolskoj ustanovi su:
a) podizanje ruke ili mahanje;
b) zagrljaj;
c) poljubac;
d) klimanje glavom;
e) nešto drugo (ukratko opišite):

5. Na koji način Vas deca oslovljavaju?
a) Oslovljavaju me imenom;
b) oslovljavaju me nadimkom;
c) oslovljavaju me rečju ,vaspitačice/vaspitaču”;
d) nešto drugo:

6. Kakvo je Vaše mišljenje o načinu oslovljavanja vaspitača u predškolskim ustanovama?
a) Deca treba da oslovljavaju vaspitače rečju „vaspitačice/vaspitaču”;
b) deca treba da oslovljavaju vaspitače ličnim imenom (prezimenom, nadimkom);
c) nisam siguran/na kako deca treba da oslovljavaju svoje vaspitače;
d) nešto drugo:

7. Ko, prema Vašem mišljenju, treba da nauči decu pravilnom oslovljavanju u predškolskoj ustanovi?
a) Vaspitači;
b) roditelji/staratelji;
c) i vaspitači i roditelji/staratelji;
d) neko drugi:

8. Kako Vi oslovljavate decu u svojoj vaspitnoj grupi?
a) Oslovljavam ih imenom;
b) oslovljavam ih prezimenom;
c) oslovljavam ih nadimcima;
d) tepam im rečima ,dušo, srce, mili/mila i sl.”;
e) nešto drugo:

9. Kako Vi oslovljavate decu u svojoj vaspitnoj grupi (kada je reč o grupi dece)?
a) Oslovljavam ih rečju „deco”;
b) oslovljavam ih rečju ,,drugari”;
c) ponekad ih oslovljavam rečju „deco”, a ponekad rečju „drugari”; 
d) nešto drugo:

10. Na koji način Vam se deca obraćaju?

a) Deca mi persiraju (formalno obraćanje);

b) deca mi ne persiraju (neformalno obraćanje).

11. Kako bi deca, prema Vašem mišljenju, trebalo da Vam se obraćaju?
a) Smatram da bi trebalo da mi persiraju;
b) nema potrebe da mi deca predškolskog uzrasta persiraju;
c) nešto drugo:

12. Sa temom pozdravljanja, obraćanja i oslovljavanja u predškolskim ustanovama upoznali ste se (zaokružite jedan ili više ponuđenih odgovora):
a) tokom formalnog obrazovanja (u okviru nastavnih sadržaja različitih predmeta);
b) na seminarima stručnog usavršavanja;
c) tokom projektnih aktivnosti;
d) na stručnim skupovima, tribinama, konferencijama;
e) na roditeljskim sastancima i/ili sastancima stručnih aktiva;
f) Čitanjem naučnih i/ili stručnih časopisa, udžbenika, priručnika i druge literature;
g) pretraživanjem sadržaja na internetu;
h) nikada se nisam posebno bavio/la ovom temom;
i) nešto drugo:

13. Međusobno pozdravljanje, obraćanje i oslovljavanje dece i vaspitača kao stvaralački čin na praznim linijama zapišite primere neobičnih i originalnih pozdrava, neočekivano izabranih jezičkih sredstava u međusobnom verbalnom saobraćanju i oslovljavanju dece.

14. Međusobno pozdravljanje, obraćanje i oslovljavanje dece i vaspitača:
a) treba standardizovati, odnosno utvrditi jedino prihvatljivu formu pozdrava, obraćanja i oslovljavanja u kontekstu predškolske ustanove;
b) treba ostaviti na volju učesnika/ca u komunikaciji, a imajući u vidu uzrast dece;
c) postaviti standardne okvire, truditi se i podsticati komunikatore da se ti okviri poštuju, ne umanjujući pritom slobodu i kreativnost vaspitača, pogotovo dece;
d) nešto drugo (ukratko opišite): 